\title{
El componente indígena del derecho indiano y la obra de Alfonso García-Gallo
}

\section{The Indigenous Component of the Indianous Law and the Work of Alfonso García-Gallo}

\author{
Miguel Ángel GONZÁLEZ DE SAN SEGUNDO \\ Catedrático de Historia del Derecho \\ Área de Historia del Derecho. Facultad de Derecho \\ Universidad de Zaragoza
}

Recibido: 16 de noviembre de 2010

Aceptado: 18 de enero de 2011

\section{RESUMEN}

En relación con el componente indígena o autóctono considerado como uno de los elementos integrantes del derecho indiano, el presente trabajo tiene por objeto señalar algunas de las explicaciones o de las referencias que acerca de dicho componente indígena se contenían en exposiciones de conjunto y en artículos y estudios monográficos del profesor Alfonso García-Gallo, y también de otros historiadores del derecho, tanto españoles como hispano-americanos, aproximadamente hasta los años setenta del siglo XX.

PALABRAS CLAVE: Historia del derecho de la edad moderna, América española, derecho indiano, componente indígena o autóctono, obra de Alfonso García-Gallo, aportaciones de otros historiadores del derecho, siglo XX.

\begin{abstract}
In this paper I will study the indigenous or native component of Indianous Law, regarded as one of the main elements of it. This study aims to analyze the explanations and references containing about this law in Professor Alfonso García-Gallo's general expositions, articles and monographies, as well as from other legal historians, both Spanish and Latin-American, approximately until the 1970's decade.
\end{abstract}

KEYWORDS: Legal History in the modern age, Spanish America, Indianous Law, indigenous or native component, García-Gallo's work, $20^{\text {th }}$ century.

\section{RÉSUMÉ}

Dans cette étude sur la composante autochtone ou indigène du Droit Indien, on a eu lieu à le considérer comme l'un des éléments principales du dit Droit. Cette étude vise à analyser les explications et références faites sur ce droit contenues dans les expositions intégrales, les articles, et les monographies du professeur Alfonso García-Gallo et d'autres historiens du droit, Espagnol et Hispano-américain, jusque les années $70 \mathrm{du} \mathrm{XX}^{\mathrm{e}}$ siècle.

MOTS CLÉ : histoire du droit dans l'âge moderne, l'Amérique espagnole, Droit Indien, composant autochtone ou indigène. 


\section{ZUSAMMENFASSUNG}

In dieser Studie steht im Vordergrund die indigene Komponente, die als eine der wesentlichen Elemente des "derecho indiano" anzusehen ist; dazu werden die Ausführungen von Alfonso García-Gallo und anderer spanischer wie lateinamerikanischer Rechtshistoriker seit den 1970er Jahren herangezogen.

SCHLÜSSELWÖRTER: Rechtsgeschichte der Neuzeit, Hispanoamerika, derecho indiano, indigene Komponente, Werk von Alfonso García-Gallo, 20. Jahrhundert.

SUMARIO: 1. La Metodología de García-Gallo del año 1970 y sus referencias a exposiciones de conjunto sobre la historia del derecho indiano, hispano-americano y español. 2. El componente indígena del derecho indiano en algunas exposiciones de conjunto y en algunos artículos y estudios monográficos de diversos autores hasta los años setenta del siglo XX. 3. El componente indígena del derecho indiano en las exposiciones de conjunto y en los artículos y estudios monográficos del profesor García-Gallo.

\section{La Metodología de García-Gallo del año 1970 y sus referencias a exposi- ciones de conjunto sobre la historia del derecho indiano, hispano-americano y español}

Afirmaba el profesor Alfonso García-Gallo en 1970, en el parágrafo nº 11, titulado «El Derecho indígena», de su Metodología de la Historia del Derecho indiano, que «al Derecho indígena siempre se le ha considerado como no indiano», y escribía también en el mismo lugar que «algunos autores de manuales de Historia del Derecho nacional —argentino (Bunge), mexicano (Esquivel Obregón) o peruano (Basadre) se han ocupado de él [del derecho indígena] como de un sistema prehispánico que regía en el país antes de la conquista española» ${ }^{1}$.

En relación con todo ello creo, por una parte, que la primera de esas dos afirmaciones de García-Gallo - la de que «al Derecho indígena siempre se le ha considerado como no indiano»- resultaba demasiado radical y terminante como para que fuera posible sostenerla válidamente en el tiempo en el que se hacía, de tal manera que en mi opinión requiere, por lo tanto, algunas matizaciones o aclaraciones. Y, por otra parte, me parece igualmente que cabe poner de relieve la circunstancia de que los autores de manuales sobre la historia del derecho de las diversas naciones hispano-americanas señalados por García-Gallo como ejemplo para ilustrar o comprobar la segunda de sus afirmaciones - la relativa a los autores que se habían ocupado del derecho indígena «como de un sistema prehispánico que regía en el país antes de la conquista española»— eran, según decía entonces, únicamente tres: el argentino Carlos Octavio Bunge, en 1912²; el mexicano Toribio Esquivel Obregón, a partir de $1937^{3}$, y el peruano Jorge Basadre, también en $1937^{4}$.

\footnotetext{
${ }^{1}$ Alfonso García-Gallo, Metodología de la Historia del Derecho indiano, Santiago de Chile, 1970, pp. 19-20.

${ }^{2}$ Carlos Octavio Bunge, Historia del Derecho argentino, Buenos Aires, 1912. Obra no citada por García-Gallo, sin embargo, en la bibliografía sobre las exposiciones de conjunto de historia del derecho de
} 
En otro lugar de su citada monografía metodológica, al tratar acerca del método de investigación y dentro del apartado de orientación bibliográfica sobre las exposiciones de conjunto de nuestra disciplina, García-Gallo dedicaba los parágrafos $\mathrm{n}^{\circ} 250$ $\mathrm{y}^{\mathrm{o}} 251$, respectivamente, a las obras de esa índole tanto de historia del derecho indiano, en general, como de historia de los derechos nacionales de los distintos países hispano-americanos, en particular, señalando no sólo que la consulta de las mismas «es siempre indispensable», sino afirmando también al propio tiempo que en su $\mathrm{Me}$ todología «sólo se citan las más modernas y recomendables» ${ }^{5}$.

Concretamente, las exposiciones de conjunto sobre la historia del derecho indiano mencionadas en dicho parágrafo $\mathrm{n}^{\circ} 250$ de la Metodología eran las de los tres autores siguientes: el argentino Ricardo Levene, en 19246; el español José María Ots Capdequí, a partir de $1943^{7}$, y el colombiano José María Marsal, en $1959^{8}$.

Y por lo que se refiere a las obras de conjunto sobre la historia de los derechos nacionales de los distintos países hispano-americanos incluidas por el profesor García-Gallo en el parágrafo $\mathrm{n}^{\circ} 251$ de su Metodología, las mencionadas en este caso correspondían a seis de tales países: Argentina, Chile, México, Paraguay, Perú y Venezuela. Se trataba de las aportaciones del ya citado Ricardo Levene a partir de $1944^{9}$, de Ricardo Zorraquín Becú en $1966^{10}$ y de Víctor Tau Anzoátegui y Eduardo

los distintos países hispano-americanos incluida en el parágrafo ${ }^{\circ}$ 251, página 137, de su Metodología, tal vez porque le aplicaba la indicación — hecha en el parágrafo $\mathrm{n}^{\circ} 250$, página 136 , de la misma - de que «sólo se citan las más modernas y recomendables».

${ }^{3}$ Toribio Esquivel Obregón, Apuntes para la Historia del Derecho en México, 3 volúmenes, México, 1937-1948. Obra citada por García-Gallo en el parágrafo no 251, página 137, de su Metodología.

${ }^{4}$ Jorge Basadre, Historia del Derecho peruano (Nociones generales. Época prehispánica. Fuentes de la época colonial), Lima, 1937. Obra citada por García-Gallo en el parágrafo $\mathrm{n}^{\circ} 251$, página 137 , de su Metodología.

${ }^{5}$ García-Gallo, Metodología de la Historia del Derecho indiano, parágrafo no 250, p. 136.

${ }^{6}$ Ricardo Levene, Introducción a la Historia del Derecho indiano, Buenos Aires, 1924. Obra citada por García-Gallo en el parágrafo n ${ }^{\circ}$ 250, página 136, de su Metodología, donde mencionaba igualmente la $2^{\mathrm{a}}$ edición, en Obras de Ricardo Levene, Academia Nacional de la Historia, Buenos Aires, 1962, tomo III, páginas 5-265.

${ }^{7}$ José María Ots y Capdequí, Manual de Historia del Derecho español en las Indias y del Derecho propiamente indiano, 2 volúmenes, Buenos Aires, 1943. Obra citada por García-Gallo en el parágrafo n ${ }^{\circ}$ 250, página 136, de su Metodología, donde mencionaba también la $2^{\mathrm{a}}$ edición o reimpresión, en un volumen, hecha en Buenos Aires en 1945. García-Gallo proporcionaba, además, la información siguiente: «Esta obra ha sido refundida y adicionada como Historia del Derecho español en América y del Derecho indiano (Madrid, 1968)», indicando a continuación que «una obra paralela, pero más extensa, del mismo autor son sus Instituciones (Barcelona, 1959), que forman el tomo XV de la Historia de América y de los pueblos americanos dirigida por A. Ballesteros y Beretta (Barcelona, Edit. Salvat)»; García-Gallo, Metodología de la Historia del Derecho indiano, pp. 136-137.

${ }^{8}$ José María Marsal y Marcé, Síntesis histórica del Derecho español y del indiano, Bogotá, 1959. Obra citada por García-Gallo en el parágrafo n ${ }^{\circ}$ 250, página 137, de su Metodología, donde indicaba acerca de esta exposición de conjunto que «sigue de cerca el Manual de Ots».

${ }^{9}$ Ricardo Levene, Historia del Derecho argentino, 11 volúmenes, Buenos Aires, 1944-1958, y Manual de Historia del Derecho argentino, Buenos Aires, 1952. Acerca de estas obras indicaba García-Gallo 
Martiré en $1967^{11}$, en cuanto a la historia del derecho argentino; de Alamiro de Ávila Martel en $1955^{12}$ y de Jaime Eyzaguirre en $1962^{13}$, en cuanto a la historia del derecho cultivada en Chile; del también citado ya Toribio Esquivel Obregón a partir de 1937"14, en cuanto a la historia del derecho en México; de Juan José Soler en $1954^{15}$, en cuanto al derecho paraguayo; del igualmente citado Jorge Basadre en $1937^{16}$, en cuanto a la historia del derecho peruano, y de Humberto Bello Lozano en $1946^{17}$, en cuanto a la historia del derecho de Venezuela.

que la Historia del Derecho argentino «reproduce en los dos primeros tomos, puesta al día», la Introducción del año 1924 [citada en la nota 6 de este artículo] y que «añade un tercero con documentos», así como que el Manual de Historia del Derecho argentino es «un resumen de esta obra» [de la Historia del Derecho argentino]; García-Gallo, Metodología de la Historia del Derecho indiano, parágrafo ${ }^{\circ}$ 251, p. 137.

${ }^{10}$ Ricardo Zorraquín Becú, Historia del Derecho argentino, tomo I, Buenos Aires, 1966. Sobre esta obra García-Gallo hacía solamente la indicación de que «en este primer tomo abarca el Derecho indiano»; García-Gallo, Metodología de la Historia del Derecho indiano, parágrafo n 251, p. 137. El profesor Zorraquín publicaría en 1986 un artículo sobre la materia objeto de estas páginas; Ricardo Zorraquín Becú, «Los Derechos indígenas», en Revista de Historia del Derecho núm. 14, Buenos Aires, 1986, pp. 427-451.

${ }^{11}$ Víctor Tau Anzoátegui y Eduardo Martiré, Manual de Historia de las Instituciones argentinas, Buenos Aires, 1967. Obra meramente citada, sin hacer ninguna indicación sobre ella; García-Gallo, Metodología de la Historia del Derecho indiano, parágrafo $\mathrm{n}^{\circ} 251$, p. 137. El profesor Tau es autor de diversos trabajos en materia de costumbre jurídica y derecho consuetudinario; Víctor Tau Anzoátegui, «La costumbre como fuente del Derecho indiano en los siglos XVI y XVII. Estudio a través de los Cabildos del Río de la Plata, Cuyo y Tucumán», en III Congreso del Instituto Internacional de Historia del Derecho Indiano, Madrid, 1973, pp. 115-191; «La costumbre en el Derecho del siglo XVIII. La doctrina jurídica y la praxis ríoplatense a través de los Cabildos», en Memoria del IV Congreso Internacional de Historia del Derecho Indiano, México, 1976, pp. 671-725; «La costumbre jurídica en la América española (Siglos XVI-XVIII)», en Revista de Historia del Derecho núm. 14, Buenos Aires, 1986, pp. 335-425; El poder de la costumbre. Estudios sobre el Derecho consuetudinario en América Hispana hasta la emancipación, Buenos Aires, 2001.

${ }^{12}$ Alamiro de Ávila Martel, Curso de Historia del Derecho, tomo I, Santiago de Chile, 1955. En relación con esta obra, que se encontraba «en publicación», indicaba García-Gallo que «en lo aparecido hasta ahora se tratan los problemas generales de la historiografía jurídica y la formación del Derecho español hasta el comienzo de la Reconquista»; García-Gallo, Metodología de la Historia del Derecho indiano, parágrafo $n^{\circ}$ 251, p. 137. El profesor Ávila Martel publicaría en 1984, en colaboración con el profesor Bravo Lira, un artículo sobre la costumbre jurídica en Indias; Alamiro de Ávila Martel y Bernardino Bravo Lira, «Aporte sobre la costumbre en el Derecho indiano», en Revista Chilena de Historia del Derecho núm. 10, Santiago de Chile, 1984.

${ }^{13}$ Jaime Eyzaguirre, Historia del Derecho, Santiago de Chile, 1962. Acerca de esta obra hacía GarcíaGallo la aclaración de que se trataba de unas «dispensas mimeografiadas»; García-Gallo, Metodología de la Historia del Derecho indiano, parágrafo $\mathrm{n}^{\circ}$ 251, p. 137.

${ }^{14}$ Obra citada en la nota 3 de este artículo.

${ }^{15}$ Juan José Soler, Introducción al Derecho paraguayo, Madrid, 1954. García-Gallo indicaba únicamente que esta Introducción «contiene una parte histórica»; García-Gallo, Metodología de la Historia del Derecho indiano, parágrafo $\mathrm{n}^{\mathrm{o}} 251, \mathrm{p} .137$.

${ }^{16}$ Obra citada en la nota 4 de este artículo.

${ }^{17}$ Humberto Bello Lozano, Historia de las fuentes e instituciones jurídicas venezolanas, Caracas, 1946. 
El parágrafo n ${ }^{\circ} 254$ de la Metodología de la Historia del Derecho indiano del profesor García-Gallo del año 1970 tenía por objeto las exposiciones de conjunto sobre la historia del derecho español, indicándose que estas obras «han de consultarse no sólo porque el [derecho] castellano rige en Indias, sino también porque en la mayor parte de ellas se concede atención al [derecho] indiano», si bien García-Gallo hacía la salvedad de que en su Metodología «únicamente se citan las obras más modernas (omitiendo las que ya han sido superadas o no se ocupan de los tiempos modernos), que pueden ser útiles para el estudio del Derecho indiano» ${ }^{18}$. En tal sentido, y con la finalidad señalada, mencionaba algunas de las obras o exposiciones de conjunto que se habían publicado hasta el año 1968 por seis historiadores del derecho españoles: los profesores Galo Sánchez, hacia $1925^{19}$; Román Riaza, en colaboración con Alfonso García-Gallo, en 193420; el propio Alfonso García-Gallo, en 1946-1950²1 y en 1959-1962 22. José Manuel Pérez-Prendes, en $1964^{23}$; Rafael Gibert, en $1968^{24}$, y Luis García de Valdeavellano, igualmente en $1968^{25}$.

En la referencia hecha por García-Gallo se repite el adjetivo «jurídicas» (Historia de las fuentes jurídicas e instituciones jurídicas venezolanas); García-Gallo, Metodología de la Historia del Derecho indiano, parágrafo $\mathrm{n}^{\circ} 251$, p. 137.

${ }^{18}$ García-Gallo, Metodología de la Historia del Derecho indiano, pp. 138-139.

${ }^{19}$ Galo Sánchez, Curso de Historia del Derecho. Citaba García-Gallo la 9a edición corregida, Curso de Historia del Derecho. Introducción y fuentes, Madrid, 1960, y, aunque omitía el subtítulo de Introducción y fuentes, hacía, sin embargo, la indicación de que esta obra «sólo se ocupa de las fuentes»; GarcíaGallo, Metodología de la Historia del Derecho indiano, parágrafo nº 254, p. 139.

${ }^{20}$ Román Riaza y Alfonso García-Gallo, Manual de Historia del Derecho español, Madrid, 1934. En relación con esta obra señalaba García-Gallo que «se recomienda aquí la parte redactada por Riaza»; GarcíaGallo, Metodología de la Historia del Derecho indiano, parágrafo n ${ }^{\circ} 254$, p. 139. Sobre las partes y los parágrafos cuya redacción corresponde a cada uno de los dos coautores véase la nota 112 de este artículo. ${ }^{21}$ Alfonso García-Gallo, Curso de Historia del Derecho español, 2 volúmenes, Madrid, 1946-1950. De este Curso de Historia del Derecho español citaba García-Gallo la $6^{\text {a }}$ edición, del año 1956, haciendo la indicación de que «se recomienda por la parte que no tiene paralelo en la siguiente» [es decir: en su propio Manual de los años 1959-1962]; García-Gallo, Metodología de la Historia del Derecho indiano, parágrafo $\mathrm{n}^{\mathrm{0}} 254$, p. 139. Otra de las exposiciones de conjunto de García-Gallo, el Tratado de Historia del Derecho español, 2 volúmenes, Madrid, 1940-1942, no se citaba en el parágrafo no 254 de su $\mathrm{Me}$ todología, por ser una de las obras que «no se ocupan de los tiempos modernos».

${ }^{22}$ Alfonso García-Gallo, Manual de Historia del Derecho español, 2 volúmenes (volumen I, El origen y la evolución del Derecho; volumen II, Metodología histórico-jurídica y Antología de fuentes del antiguo Derecho español), Madrid, 1959-1962. De su Manual de Historia del Derecho español citaba GarcíaGallo la $3^{\text {a }}$ edición, del año 1967, haciendo en este caso la afirmación siguiente: «Este Manual constituye una obra radicalmente distinta de las otras similares del autor, tanto por su concepción como por su contenido, concediendo amplia atención al Derecho indiano», e indicando también que «lo que en esta obra se encuentra anula lo contenido sobre lo mismo en el primitivo Manual publicado con Riaza y en el Curso»; García-Gallo, Metodología de la Historia del Derecho indiano, parágrafo nº 254, p. 139.

${ }^{23}$ José Manuel Pérez-Prendes, Apuntes de Historia del Derecho español, Madrid, 1964. Advertía García-Gallo que estos Apuntes están «dirigidos a los alumnos», lo cual, dada la naturaleza y la finalidad de los mismos, creo que debía entenderse rectamente como un elogio; García-Gallo, Metodología de la Historia del Derecho indiano, parágrafo $\mathrm{n}^{\circ} 254$, p. 139. 
2. El componente indígena del derecho indiano en algunas exposiciones de conjunto y en algunos artículos y estudios monográficos de diversos autores hasta los años setenta del siglo XX

Antes de referirme más adelante, en el epígrafe número 3 de este trabajo, a la obra del profesor Alfonso García-Gallo en relación con la materia objeto de las presentes páginas, menciono en primer lugar algunas exposiciones de conjunto y algunos artículos y estudios monográficos de diversos autores, tanto hispano-americanos como españoles, y publicados en principio durante el siglo XX y hasta la década del año 1970, en que apareció la siempre referida Metodología de la Historia del Derecho indiano, en lo que tienen que ver con el aspecto del componente o elemento indígena de dicho ordenamiento jurídico.

\section{A) El componente indígena del derecho indiano en algunas exposiciones de conjunto de diversos autores hasta la década del año 1970}

Por lo que corresponde a las explicaciones o a las referencias que sobre el componente indígena o autóctono como uno de los elementos integrantes del derecho indiano se han hecho en algunas exposiciones de conjunto, tanto de historia del derecho indiano como de historia del derecho español, publicadas hasta la década del año 1970 por diversos autores, se trata en este artículo, por una parte, de las obras del argentino Ricardo Levene y del peruano Jorge Basadre, y, por otra parte, de las obras de los catedráticos españoles de Historia del Derecho Galo Sánchez, Salvador Minguijón, Juan Beneyto, José María Ots Capdequí, José Manuel Pérez-Prendes y Jesús Lalinde Abadía. Son obras por lo general citadas, pero en algún caso no citadas, en la Metodología de García-Gallo.

En primer término, me parece que será oportuno señalar aquí que el profesor García-Gallo no mencionaba en su Metodología del año 1970 la obra publicada por Ricardo Levene en el año 1918, titulada Notas para el estudio del Derecho indiano ${ }^{26}$, en

\footnotetext{
${ }^{24}$ Rafael Gibert, Historia general del Derecho español, tomo I, Granada, 1968; con varias reimpresiones posteriores, hechas en Madrid en diferentes años. Esta obra era meramente citada por García-Gallo en el parágrafo $\mathrm{n}^{\mathrm{0}} 254$, página 139, de su Metodología, sin hacer ninguna observación o comentario sobre ella. Acerca del contenido de esta Historia general, su propio autor indicaba lo siguiente: «Las dimensiones alcanzadas por lo impreso aconsejaban entregar al público esta primera parte, que comprende hasta el fin de la época austríaca, con excepción de Indias y derecho indiano, y de la Inquisición»; Gibert, Historia general del derecho español, «Prólogo», p. XIII.

${ }^{25}$ Luis G[arcía] de Valdeavellano, Curso de Historia de las instituciones españolas. I, De los orígenes al final de la Edad Media, Madrid, 1968 [año 1967, en la referencia hecha en la Metodología de García-Gallo; pero me parece que la $1^{a}$ edición era del año 1968]. Sobre esta obra hacía García-Gallo la indicación de que «aunque en la parte publicada no abarca la Edad Moderna, merece tenerse en cuenta»; García-Gallo, Metodología de la Historia del Derecho indiano, parágrafo nº 254, p. 139.

${ }^{26}$ Ricardo Levene, Notas para el estudio del Derecho indiano, Buenos Aires, 1918. García-Gallo no ci-
} 
la cual se contenía, ya en dicho año 1918, la certera afirmación de que «no pocas instituciones indígenas» sobrevivieron, con su «organización jurídica típica», en el derecho indiano. Afirmaba Levene - en 1918, insisto, no en 1924- que «aparte de la influencia incontrarrestable de los factores geográfico y económico, concurrió a marcar con sello indeleble a este nuevo Derecho [el derecho indiano] la composición social y étnica de las nuevas sociedades, en cuyo seno no pocas instituciones indígenas supervivieron con su sangre, costumbres, cultura general y organización jurídica típica ${ }^{27}$.

El mismo Levene, en su Introducción a la Historia del Derecho indiano, obra mencionada en el parágrafo $\mathrm{n}^{\circ} 250$ de la Metodología de García-Gallo y publicada en el año $1924^{28}$, escribía que «el Derecho indígena sobrevivió después de la conquista española e inspiró la legislación indiana más de lo que comúnmente se admite» ${ }^{29} ; \mathrm{y}$ también que «se advierte le enorme influencia ejercida por el despliegue de las costumbres de los naturales de América, si se tiene presente que no pocas instituciones legisladas por España se refieren sustancialmente a modalidades típicas de la organización de los indios», señalando, por ejemplo, que «el régimen tributario impuesto a los indios por los españoles se erigió sobre la base de la organización existente» ${ }^{30}$.

Por otro lado, lo que afirmaba García-Gallo en relación con la obra publicada por Jorge Basadre en 1937, la ya citada Historia del Derecho peruano ${ }^{31}$, al incluirla entre los manuales que se habían ocupado del derecho indígena únicamente «como de un sistema prehispánico que regía en el país antes de la conquista española ${ }^{32}$, me parece que requiere alguna aclaración o matización. La afirmación de García-Gallo, en este caso, solamente sería exacta en cuanto al libro segundo de esa Historia del Derecho de Basadre, que estaba dedicado precisamente a la «Época pre-hispánica» y que comprendía los capítulos quinto a undécimo de la misma.

Pero lo que no mencionaba García-Gallo es que en el libro tercero, sobre «El desenvolvimiento del Derecho peruano desde la época de la conquista española. Bases de la formación del Derecho colonial», y dentro de su capítulo decimosexto, que trataba de explicar «El sentido del Derecho indiano», en el parágrafo $n^{\circ} 11$, titulado precisamente «Derecho indígena», Basadre se refería literalmente a las que consideraba las «tres formas» de permanencia del derecho indígena en el ordenamiento jurídico indiano, las cuales habrían sido éstas: la influencia indígena en la legislación, la po-

taba tampoco en su Metodología el artículo de Ricardo Levene, «El Derecho consuetudinario y la doctrina de los juristas en la formación del Derecho indiano», en The Hispanic American Historical Review vol. III, núm. 2, Baltimore, 1920, pp. 144-151.

${ }^{27}$ Levene, Notas para el estudio del Derecho indiano, p. 5.

${ }^{28}$ Levene, Introducción a la Historia del Derecho indiano, Buenos Aires, 1924, obra citada ya en la nota 6 de este artículo.

${ }^{29}$ Levene, Introducción a la Historia del Derecho indiano, p. 34.

${ }^{30}$ Levene, Introducción a la Historia del Derecho indiano, pp. 35-36.

${ }^{31}$ Basadre, Historia del Derecho peruano, Lima, 1937, citada ya en la nota 4 de este artículo.

${ }^{32}$ García-Gallo, Metodología de la Historia del Derecho indiano, parágrafo no 11, p. 20. 
sibilidad de que se mantuvieran determinados usos indígenas y la vigencia —en su opinión- de costumbres indígenas contra legem para la regulación de algunas materias. Escribía Basadre, a este respecto, lo siguiente: «Además tiénese el problema del derecho consuetudinario indígena como fuente supletoria. Cabe señalar tres formas de su permanencia en la colonia. $1^{\circ}$. La influencia indígena en la legislación que tiene más importancia de lo que se cree en la mita, en el tributo, etc. Los apologistas del virrey Toledo aluden justamente a que este virrey se inspiró en el derecho indígena. $2^{\circ}$. La facultad para que funcionasen los usos indígenas no opuestos a la legislación o a la religión católica. $3^{\circ}$. La vigencia de las costumbres indígenas en contra de la ley, en lo que se refiere a la propiedad, derecho familiar, etc. $\rangle^{33}$.

En cuanto a la cuestión del componente indígena del derecho indiano como materia explicada, o al menos mencionada, en algunas exposiciones de conjunto de varios catedráticos españoles de Historia del Derecho hasta la década del año 1970, en el que apareció la Metodología de la Historia del Derecho indiano de García-Gallo, me refiero brevemente a las obras publicadas por los profesores Galo Sánchez hacia el año 1925, Salvador Minguijón en 1927, Juan Beneyto en 1940 y en 1958, José María Ots y Capdequí a partir de 1943 y en 1968, José Manuel Pérez-Prendes en 1964 y Jesús Lalinde Abadía en 1970.

Galo Sánchez publicó por primera vez hacia el año 1925 el que sería su Curso de Historia del Derecho ${ }^{34}$, del cual se hicieron, como es bien sabido, numerosas ediciones posteriores. Al parecer, la primera edición procede del año $1924^{35}$, o bien del curso académico 1925-1926 ${ }^{36}$, en forma de Apuntes tomados de las explicaciones del catedrático, y como «sencillos apuntes litografiados» según la indicación de Gibert ${ }^{37}$. Acerca de su Curso, el propio don Galo escribiría, muchos años después, lo siguiente: «Sin duda, el éxito logrado por este libro se debe, en parte, a no existir ningún otro

\footnotetext{
${ }^{33}$ Basadre, Historia del Derecho peruano, p. 281.

${ }^{34}$ Galo Sánchez, Curso de Historia del Derecho; obra citada en la nota 19 de este artículo. Entre las numerosas ediciones que existen, he podido tener a la vista la titulada Curso de Historia del Derecho. Apuntes tomados de las explicaciones del catedrático de la asignatura en la Universidad Central, Madrid, 1940, en la cual no se señalaba el nombre del autor, además de la ya mencionada Curso de Historia del Derecho. Introducción y fuentes, $9^{\mathrm{a}}$ edición corregida, Madrid, 1960. Cito aquí por esta $9^{\mathrm{a}}$ edición corregida, que fue «la última edición revisada por el autor», según se indicaba después en la $10^{\mathrm{a}}$ edición, revisada por José Antonio Rubio Sacristán, Valladolid, 1972, «Prólogo a la décima edición», p. 6.

${ }^{35} \mathrm{La}$ aparición o primera edición del que sería titulado más tarde Curso de Historia del Derecho de don Galo es situada por Sánchez-Arcilla en el año 1924, y habría tenido entonces el título de Apuntes de Historia general del Derecho, según las explicaciones del catedrático de la asignatura en la Universidad de Barcelona; José Sánchez-Arcilla Bernal, Jacobus, id quod ego. Los caminos de la ciencia jurídica, Madrid/Sevilla, 2003, p. 20 y nota 42.

${ }^{36}$ Rubio Sacristán, «Prólogo a la décima edición», p. 5.

${ }^{37}$ Rafael Gibert, «Curso de Historia del Derecho español», recensión publicada en la revista Arbor, del Consejo Superior de Investigaciones Científicas, en 1946, y reproducida también en la $10^{\text {a }}$ edición, del año 1972, del Curso de don Galo, pp. 7-9.
} 
análogo en el momento de su aparición $»^{38}$. Sobre la cuestión del elemento indígena del ordenamiento jurídico indiano, en el epígrafe titulado «Otras fuentes del Derecho indiano» - dentro de la sección VI, Edad Moderna; apartado D), Leyes de Indiasdon Galo Sánchez afirmaba simplemente, con su característica concisión, que «la validez del Derecho consuetudinario indígena fue admitida también en ciertos casos $\rangle^{39}$.

Salvador Minguijón publicó a partir del año 1927 su Historia del Derecho ${ }^{40}$, editada al menos cuatro veces. En la parte dedicada a exponer «El Derecho español en América», y en relación con la materia del componente indígena del derecho indiano, el profesor Minguijón se limitaba a citar a Ricardo Levene e indicaba lo siguiente: «A juicio de Levene se advierte la enorme influencia ejercida por el despliegue de las costumbres de los naturales de América, si se tiene presente que no pocas instituciones legisladas por España se refieren substancialmente a modalidades típicas de la organización de los indios» $\rangle^{41}$.

Juan Beneyto publicó en 1940 su Manual de Historia del Derecho ${ }^{42}$ y en 1958 su Historia de la Administración ${ }^{43}$. En el Manual de Historia del Derecho afirmaba, por lo que se refiere al asunto de referencia en el presente artículo, que «la costumbre indígena era respetada no sólo a través de los órganos de aplicación del Derecho (...), sino en la ley misma» ${ }^{44}$. Y en la Historia de la Administración el profesor Beneyto aludía a diversos aspectos de interés para la cuestión del componente indígena o autóctono como, por ejemplo, el intento de que la tributación indígena fuera como en la época prehispánica: «En esta misma materia es interesante recoger aquella serie de preguntas que inserta el Cedulario, de Puga, sobre las cuales se intentó basar la tributación indiana en el recuerdo del sistema precolombino. Si se tiene en cuenta que esta disposición es de 1553, puede advertirse que el problema de incorporar un sistema fiscal a la vida administrativa estaba aún entonces pendiente y testimoniaba la dificultad de trasladar los regímenes establecidos en la metrópoli»; se ocupaba también de la tributación de los indios comunes a los caciques: «Todo este conjunto va sistematizándose a mediados del siglo XVI, cuando se tasan las contribuciones de los indígenas para con sus caciques, del mismo modo en que lo eran las que percibían los gobernadores y las comunidades religiosas»; y de la tasación y la moderación del tributo indígena, indicando que «se enviaron comisionados-visitadores para tasar y

\footnotetext{
${ }^{38}$ Sánchez, «Advertencia», en la citada $9^{a}$ edición, del año 1960, de su Curso de Historia del Derecho.

${ }^{39}$ Sánchez, Curso de Historia del Derecho, p. 182.

${ }^{40}$ Salvador Minguijón Adrián, Historia del Derecho español, Barcelona, 1927. Existen varias ediciones posteriores: una $2^{\mathrm{a}}$ edición del año 1933; una $3^{\mathrm{a}}$ edición, revisada, del año 1943 , y una $4^{\mathrm{a}}$ edición, también revisada, del año 1953. Cito aquí por esta $4^{\text {a }}$ edición, Barcelona, 1953.

${ }^{41}$ Minguijón, Historia del Derecho español, p. 418.

${ }^{42}$ Juan Beneyto, Manual de Historia del Derecho español, Zaragoza, 1940; $2^{\mathrm{a}}$ edición o reimpresión Zaragoza, 1948, por la cual lo cito en este artículo.

${ }^{43}$ Juan Beneyto, Historia de la Administración española e hispanoamericana, Madrid, 1958.

${ }^{44}$ Beneyto, Manual de Historia del Derecho español, p. 176.
} 
moderar la tributación indígena $\rangle^{45}$. En cuanto al poder ejercido por los caciques, escribía Beneyto: «Por bajo de la organización territorial, la vida local estaba regida por los caciques. Todo se hacía, según cuentan las crónicas, por mano de los más principales, que eran muy obedecidos y estimados» ${ }^{46}$.

José María Ots y Capdequí publicó a partir de 1943 su Manual de Historia del Derecho ${ }^{47}$ y en 1968 su Historia del Derecho español e indiano ${ }^{48}$, la cual era una «reelaboración» del anterior Manual. En la parte segunda de esa Historia del Derecho, parte titulada «El Derecho indiano» (dentro del apartado I, «Hechos que condicionaron el nacimiento y desarrollo histórico del Derecho indiano»; epígrafe 5, «La pugna entre las tendencias uniformadoras de los monarcas y el imperativo de las realidades geográficas, sociales y económicas»), trataba acerca de la costumbre jurídica, haciendo la afirmación de que «tuvieron que aceptarse prácticas consuetudinarias que las circunstancias imponían. Se desarrolló así, al lado del Derecho legal, un Derecho consuetudinario, cuya importancia no es lícito desdeñar. Ya advirtió esto el historiador argentino Ricardo Levene y, con mayor amplitud, el maestro español don Rafael Altamira»; e igualmente escribía en el mismo lugar que «debemos cerrar este apartado recordando que después de la conquista también continuaron en vigor primitivas costumbres de los aborígenes, que no fueron expresamente condenadas por los legisladores españoles $\rangle^{49}$. Por otro lado, el profesor Ots Capdequí señalaba, por ejemplo, que las tasaciones de los tributos se hacían «procurando que en ningún caso excediera el montante de lo que los indios tributasen antes de la conquista a sus reyes y señores $»^{50}$.

José Manuel Pérez-Prendes publicó sus Apuntes de Historia del Derecho en el año $1964^{51}$. En relación con la materia del componente indígena del derecho indiano explicaba que «el Derecho indígena conservó toda su fuerza en los territorios de América siempre que no fuese contrario a los principios fundamentales de la religión católica y a las leyes reales que, con destino a tales zonas, se iban promulgando» ${ }^{52}$; y entre las «otras fuentes» del ordenamiento jurídico indiano mencionaba, en ese sentido, «las descripciones de los usos y costumbres de los indígenas $»^{53}$. Sobre las formas

\footnotetext{
${ }^{45}$ Beneyto, Historia de la Administración española e hispanoamericana, p. 428.

${ }^{46}$ Beneyto, Historia de la Administración española e hispanoamericana, p. 433.

${ }^{47}$ Ots y Capdequí, Manual de Historia del Derecho español en las Indias y del Derecho propiamente indiano, 2 volúmenes, Instituto de Historia del Derecho Argentino, Buenos Aires, 1943; 2a edición, en un volumen, Editorial Losada S.A., Buenos Aires, 1945. Obra citada ya en la nota 7 de este artículo. ${ }^{48}$ Ots y Capdequí, Historia del Derecho español en América y del Derecho indiano, Madrid, 1968; obra citada en la nota 7 de este artículo. Como el propio autor indicaba en la «Advertencia preliminar», página XI, este libro «es una reelaboración» de su Manual de Historia del Derecho español en las Indias y del Derecho propiamente indiano, citado en la nota anterior.

${ }^{49}$ Ots y Capdequí, Historia del Derecho español en América y del Derecho indiano, p. 88.

${ }^{50}$ Ots y Capdequí, Historia del Derecho español en América y del Derecho indiano, p. 212.

${ }^{51}$ Pérez-Prendes, Apuntes de Historia del Derecho español, Madrid, 1964; obra citada en la nota 23 de este artículo.

${ }^{52}$ Pérez-Prendes, Apuntes de Historia del Derecho español, p. 603.

${ }^{53}$ Pérez-Prendes, Apuntes de Historia del Derecho español, p. 611.
} 
de la organización indígena, el profesor Pérez-Prendes se refería a los pueblos de indios: «Junto a los pueblos de españoles surgen también los pueblos de indios o reducciones»; a la situación de los caciques y la institución del cacicazgo: «A los viejos caciques indios se les suele conservar su autoridad, pero procurando adaptarla a la nueva concepción municipal aportada por Castilla»; a las autoridades locales en los pueblos de indios: «Los caciques indios en estos pueblos designan a los oficiales»; y al sometimiento de los caciques a las audiencias y a la regulación del cacicazgo: «El cacicazgo se somete a la Audiencia y sus funciones son ordenadas $\rangle^{54}$. También, acerca del tributo indígena, hacía la indicación de que «hubo una serie de exenciones favorables a los caciques, sus hijos mayores; los alcaldes de pueblos de indios $(\ldots)\rangle^{55}$.

Jesús Lalinde Abadía publicó por primera vez su Iniciación histórica en $1970^{56}$, en el mismo año que la Metodología de la Historia del Derecho indiano de Alfonso García-Gallo. En el capítulo XXI de su Iniciación histórica, titulado «La recopilación del Derecho en los territorios oceánicos» (apartado IV, «El Derecho de los indígenas»; parágrafo $\mathrm{n}^{\circ} 317$, «El reconocimiento del Derecho autóctono de los indígenas desde el siglo XVI y la ausencia de efectos prácticos»), afirmaba que «el Derecho castellano no ha desconocido el Derecho indígena, que reconoce en 1555, cuando Carlos I y doña Juana disponen que las "leyes y buenas costumbres" de los indios para el buen gobierno y policía, así como sus "usos y costumbres" sean observados, si no se encuentran con la religión o con las leyes», y que «la disposición [del año 1555] supone el reconocimiento amplio del Derecho indígena y no pierde vigencia, pues es recopilada»; si bien añadía que, «sin embargo, el reconocimiento no tiene efectos prácticos» ${ }^{57}$. Por otra parte, en el parágrafo $\mathrm{n}^{\circ} 323$, «Orientación bibliográfica» del mismo capítulo XXI de su Iniciación histórica, escribía el profesor Lalinde, no obstante su afirmación anterior, que «sobre reconocimiento del Derecho autóctono faltan trabajos en la dirección indicada en el texto, aunque J. Manzano aborda en 1967 la cuestión de las leyes y costumbres indígenas en el orden de prelación de fuentes del Derecho indiano» ${ }^{58}$.

Cabría añadir a las obras que he mencionado hasta ahora algunas otras exposiciones de conjunto sobre la historia del derecho español aparecidas muy poco tiempo después del año 1970, como las publicadas por los profesores José Manuel PérezPrendes, en $1973^{59}$; Jesús Lalinde Abadía, en $1974^{60}$, y Francisco Tomás y Valiente,

\footnotetext{
${ }^{54}$ Pérez-Prendes, Apuntes de Historia del Derecho español, p. 737.

${ }^{55}$ Pérez-Prendes, Apuntes de Historia del Derecho español, p. 754.

${ }^{56}$ Jesús Lalinde Abadía, Iniciación histórica al Derecho español, Barcelona, 1970; $2^{\mathrm{a}}$ edición actualizada, Barcelona, 1978 (por la cual cito en esta ocasión); $3^{\text {a }}$ edición Barcelona, 1983; $4^{\text {a }}$ edición reformada, Barcelona, 1989.

${ }^{57}$ Lalinde Abadía, Iniciación histórica al Derecho español, p. 212.

${ }^{58}$ Lalinde Abadía, Iniciación histórica al Derecho español, p. 216.

${ }^{59}$ José Manuel Pérez-Prendes, Curso de Historia del Derecho español. Introducción y Parte general, Madrid, 1973; 2 2a edición Madrid, 1978 (por la cual cito en este artículo). Existen otras ediciones posteriores. ${ }^{60}$ Jesús Lalinde Abadía, Derecho histórico español, Barcelona, 1974; $3^{\mathrm{a}}$ edición Barcelona, 1983.
} 
en $1979^{61}$. En la segunda de ellas, el Derecho histórico español del año 1974, Jesús Lalinde no trataba, según creo, acerca de la cuestión del componente indígena del derecho indiano.

José Manuel Pérez-Prendes publicó en 1973 su Curso de Historia del Derecho, del cual se han hecho varias ediciones. En el capítulo veintidós - dentro del apartado A), «El Derecho indiano: concepto, elementos, etapas y características»— explicaba que «el Derecho indígena conservó su fuerza en los territorios de América siempre que no fuese contrario a los principios fundamentales de la religión católica y a las leyes reales que, con destino a tales zonas, se iban promulgando» ${ }^{62}$. Y en el mismo capítulo veintidós — dentro del apartado D), «Orden de prelación de fuentes»— hacía la siguiente indicación: «En 1555 se declara de aplicación el Derecho indígena prehispano ("leyes y buenas costumbres que antiguamente tenían los indios") que haya pervivido después de la incorporación ("usos y costumbres guardadas después que son cristianos") y no contradiga el Derecho indiano ni la Religión católica ("no se encuentren con nuestra sagrada Religión, ni con las leyes de este libro y las que se han hecho y ordenado de nuevo")» ${ }^{63}$.

Francisco Tomás y Valiente publicó en 1979 su Manual de Historia del Derecho español. En el parágrafo número 6, apartado c), del capítulo XIX, dentro del epígrafe titulado «La costumbre como fuente del Derecho de Indias», indicaba sobre el componente indígena de este ordenamiento jurídico que «una ley de Carlos V en 1555 permitía que las leyes y costumbres de la población indígena, siempre que no se enfrentaran con la religión católica ni con las leyes de Indias, se guardaran y ejecutaran»; a lo cual añadía que «a juicio de Manzano estas normas indígenas, legales o consuetudinarias, deberían ser aplicadas antes que el Derecho supletorio castellano» ${ }^{64}$.

\section{B) El componente indígena del derecho indiano en algunos artículos y estu- dios monográficos de diversos autores hasta la década del año 1970}

Señalo a continuación diversos artículos y estudios monográficos, no citados en la Metodología de la Historia del Derecho indiano de García-Gallo, que contenían explicaciones o referencias sobre la materia que constituye el objeto de este artículo. En relación con algunos de esos estudios monográficos pienso, por ejemplo, en varias de las aportaciones publicadas en Argentina y en México por el profesor Altamira a lo largo de los años cuarenta del siglo XX, concretamente en $1941^{65}$, en $1948^{66}$ y en

\footnotetext{
${ }^{61}$ Francisco Tomás y Valiente, Manual de Historia del Derecho español, Madrid, 1979. Cito aquí por la $4^{a}$ edición, Madrid, 1983, en la cual se hacía constar que no se había modificado, respecto a la $1^{\text {a }}$ edición, lo escrito en relación con esta materia.

${ }^{62}$ Pérez-Prendes, Curso de Historia del Derecho español, p. 692.

${ }^{63}$ Pérez-Prendes, Curso de Historia del Derecho español, p. 705.

${ }^{64}$ Tomás y Valiente, Manual de Historia del Derecho español, p. 341.

${ }^{65}$ Rafael Altamira, Análisis de la Recopilación de las Leyes de Indias de 1680, Buenos Aires, 1941.

${ }^{66}$ Rafael Altamira, Manual de investigación de la Historia del Derecho indiano, México, 1948.
} 
1949 ${ }^{67}$. Como es sabido, don Rafael Altamira se había ausentado definitivamente de España en 1936, trasladándose primero, en dicho año 1936, a Holanda, donde continuó su actividad como juez titular del Tribunal Internacional de Justicia, con sede en La Haya; en 1940, con motivo de la invasión y la ocupación de los Países Bajos por las tropas alemanas, se desplazó a Bayona (Francia); y en 1944, por último, se estableció en la ciudad de México, donde fallecería el 1 de junio de 1951.

Creo que las mencionadas aportaciones de Altamira sobre la historia del derecho indiano, que no citaba García-Gallo en su Metodología del año 1970, deben ser puestas de relieve en este lugar. Lo hago así, en todo caso, porque - como recordaba Eduardo Martiré en 1996, en el Homenaje de la Universidad Complutense de Madrid a Alfonso García-Gallo ${ }^{68}$ - los historiadores del derecho Ricardo Levene (a cuyas obras de historia del derecho indiano y de historia del derecho argentino me refiero en los epígrafes 1 y 2 ,A de este artículo) y Rafael Altamira «son, podemos decir con toda exactitud, los fundadores de los estudios de Historia del Derecho indiano, el uno en Argentina y el otro en España», afirmación a la cual añadía Martiré: «según palabras de Alamiro de Ávila Martel» ${ }^{69}$.

Es cierto, desde luego, que algunos trabajos de Altamira aparecían citados en la Metodología del año 1970 de García-Gallo. Así, en el parágrafo no 77 de la misma, en relación con las ordenanzas y otras disposiciones de derecho criollo y sobre la «importancia de estas fuentes» ${ }^{70}$, se mencionaban dos artículos de Altamira de los años $1941^{71}$ y $1944^{72}$; y en el parágrafo $\mathrm{n}^{\mathrm{o}} 214$, sobre las colecciones de documentos «de carácter general referentes a toda América» ${ }^{73}$, se incluían la colección que había publicado Altamira a partir del año $1926^{74}$ y también la colección publicada en colaboración con Montoto a partir del año $1927^{75}$. Por otra parte, además, ya en la $\mathrm{Me}$ moria de la oposición de García-Gallo a la cátedra de Historia del Derecho de la Universidad de Murcia, celebrada en el año 1935 y a la cual aludo más adelante en

\footnotetext{
${ }^{67}$ Rafael Altamira, Estudios sobre las fuentes de conocimiento de la Historia del Derecho indiano. La costumbre jurídica en la colonización española, México, 1949.

${ }^{68}$ Eduardo Martiré, «García-Gallo y el Instituto Internacional de Historia del Derecho Indiano», en Homenaje al profesor Alfonso Garcia-Gallo, Madrid, 1996, tomo I, pp. 69-88.

${ }^{69}$ Martiré, «García-Gallo y el Instituto Internacional de Historia del Derecho Indiano», p. 76.

${ }^{70}$ García-Gallo, Metodología de la Historia del Derecho indiano, parágrafo no 77, p. 60.

${ }^{71}$ Rafael Altamira, «La aprobación y confirmación de las leyes dadas por las autoridades coloniales españolas. Siglos XVI y XVII», en Contribuciones para el estudio de la Historia de América. Homenaje al Dr. Emilio Ravignani, Buenos Aires, 1941, pp. 39-52.

${ }^{72}$ Rafael Altamira, «Autonomía y descentralización legislativa en el régimen colonial español. Siglos XVI a XVIII», en Boletim da Faculdade de Direito da Universidade de Coimbra, núm. 20, 1944, pp. $1-71$.

${ }^{73}$ García-Gallo, Metodología de la Historia del Derecho indiano, parágrafo no 214, p. 121.

${ }^{74}$ Rafael Altamira, Colección de textos para el estudio de la historia y de las instituciones de América, 4 volúmenes, Madrid, 1926 y siguientes.

${ }^{75}$ Santiago Montoto y Rafael Altamira, Colección de documentos inéditos para la Historia de Iberoamérica, 14 volúmenes, Madrid, 1927 y siguientes.
} 
este artículo, eran mencionadas dos obras histórico-jurídicas de Altamira ${ }^{76}$, de los años $1903^{77}$ y $1914^{78}$.

En relación con la materia que constituye el objeto preferente de estas páginas, me ocupo ahora con toda brevedad de las citadas monografías que el profesor Altamira publicó en Argentina y en México durante los años cuarenta del siglo XX. En la primera de ellas, titulada Análisis de la Recopilación de las Leyes de Indias de 1680, obra aparecida en el año 1941, Altamira daba cuenta de que en su proyectada, y realizada en buena medida, serie de «Estudios sobre las fuentes de conocimiento del Derecho indiano» había considerado oportuno dedicar a esta cuestión del componente indígena del derecho indiano la parte séptima de dicha serie, parte a la que dio la denominación de «Costumbres y legislación indígenas» ${ }^{79}$.

Por lo que se refiere a la segunda de dichas obras de Altamira, su Manual de investigación de la Historia del Derecho indiano, publicado en el año 1948, eran varias las afirmaciones y las indicaciones, creo que de gran interés, que contenía en relación con la materia del elemento indígena del ordenamiento jurídico indiano. Hacía Altamira, por ejemplo, la declaración de que sus propios trabajos sobre la recién aludida parte séptima de esa serie de «Estudios sobre las fuentes de conocimiento del Derecho indiano», como también algunos otros escritos acerca de la misma materia, los tenía entonces, en 1948, «preparados en cuanto a lo fundamental $»^{80}$. Más adelante, al mencionar de forma directa la cuestión de lo que denominaba allí «los restos del Derecho indígena, tanto los incorporados al español como los independientes de este elemento», señalaba que el componente indígena del derecho indiano «está pidiendo a voces un estudio a fondo, hacia el que he procurado inclinar a varios de mis discípu$\operatorname{los}\rangle^{81}$, puesto que — afirmaba más adelante en ese Manual de investigación — «puede decirse que en cuanto a la legislación y a la costumbre de origen indígena que vinieron a ser parte del Derecho indiano colonial, todo está por hacer» ${ }^{82}$. Y en ese sentido escribía en otro lugar lo siguiente: «A propuesta mía, la Academia de Ciencias Morales y Políticas (Madrid) incluyó el tema en uno de sus últimos concursos anteriores a 1936 », a lo cual añadía: «También esto quedó paralizado por la guerra» ${ }^{83}$.

El premio o concurso al que aludía el profesor Altamira era el premio «Conde de Torreánaz» para el trienio 1935/1937, cuyo enunciado se formuló así: «Elementos del Derecho indígena americano que se incorporaron a la legislación española de In-

\footnotetext{
${ }^{76}$ José Sánchez-Arcilla Bernal, «Las oposiciones a cátedra de don Alfonso García-Gallo», en Homenaje al profesor Alfonso García-Gallo, Madrid, 1996, tomo I, p. 143, nota 116.

${ }^{77}$ Rafael Altamira, Historia del Derecho. Cuestiones preliminares, Madrid, 1903.

${ }^{78}$ Rafael Altamira, Cuestiones de Historia del Derecho y de legislación comparada, Madrid, 1914.

${ }^{79}$ Altamira, Análisis de la Recopilación de las Leyes de Indias de 1680, pp. 15-16; también en su Manual de investigación de la Historia del Derecho indiano, p. 155.

${ }^{80}$ Altamira, Manual de investigación de la Historia del Derecho indiano, p. VIII.

${ }^{81}$ Altamira, Manual de investigación de la Historia del Derecho indiano, p. 25.

${ }^{82}$ Altamira, Manual de investigación de la Historia del Derecho indiano, p. 120.

${ }^{83}$ Altamira, Manual de investigación de la Historia del Derecho indiano, p. 25, nota 19.
} 
dias (cédulas reales, ordenanzas de virreyes, ordenanzas municipales, etc.)». Dado que la guerra española de 1936 impidió cualquier actividad de esta naturaleza, la Real Academia de Ciencias Morales y Políticas volvería a anunciarlo en 1942, con el mismo tema que en $1935^{84}$.

En cuanto a la tercera de las citadas obras de Altamira, sus Estudios sobre las fuentes de conocimiento de la Historia del Derecho indiano. La costumbre jurídica en la colonización española, aparecida en el año 1949, se trataba de una monografía realizada, fundamental y casi exclusivamente, a base de la Recopilación de Indias de 1680 , ya durante el exilio de su autor. Me he propuesto no ocuparme en esta ocasión de los artículos y los estudios monográficos que se han publicado acerca del derecho consuetudinario en general y sobre la costumbre como fuente del derecho indiano, aunque sería posible hacerlo y tomar en consideración aquí ese planteamiento o esa perspectiva, dado que la presencia y la acción del elemento indígena o autóctono parecen estar estrechamente vinculadas, en principio, con la materia de la formulación popular o consuetudinaria del derecho en este ordenamiento jurídico. Sin entrar en las importantes cuestiones abordadas en tales estudios monográficos o en otros semejantes, voy a referirme especialmente ahora al componente indígena del derecho indiano en las obras del profesor don Juan Manzano, en las que dicho elemento era aludido en dos de sus libros, de los años 1948 y 1950, y alguno de cuyos aspectos estudiaría después, en un artículo del año 1967.

En 1948, en su estudio, ya clásico, sobre La incorporación de las Indias a la Corona de Castilla $^{85}$, el profesor Manzano hacía un cierto planteamiento de la cuestión del reconocimiento del derecho autóctono, en función de la carta o el mensaje que el emperador Carlos V, con fecha 1 de mayo de 1543, dirigió a los habitantes de los territorios situados «al mediodía y al poniente de la Nueva España», con la oferta o la propuesta de guardarles «todos sus privilegios, preeminencias, señoríos, libertades, leyes, costumbres» $\mathrm{y}$, en general, todo lo que pidieran de manera razonable y justa, incluso «para que puedan con vos hacer cualesquiera concordias y asientos». Algunos años después de su publicación por Manzano en $1948^{86}$, la Carta de Carlos V a los reyes y repúblicas de las Indias Orientales, solicitando su amistad y colaboración sería incluida también por García-Gallo en la Antología de fuentes del antiguo Derecho, volumen II de su Manual de Historia del Derecho español ${ }^{87}$.

En 1950, en el tomo primero de su Historia de las Recopilaciones de Indias ${ }^{88}$, don Juan Manzano no se ocupaba propiamente de la materia del componente autóctono

\footnotetext{
${ }^{84}$ Miguel Ángel González de San Segundo, «El elemento indígena en la formación del Derecho indiano», en Revista de Historia del Derecho núm. 11, Buenos Aires, 1983, p. 404, nota 6.

${ }^{85}$ Juan Manzano Manzano, La incorporación de las Indias a la Corona de Castilla, Madrid, 1948.

${ }^{86}$ Manzano, La incorporación de las Indias a la Corona de Castilla, pp. 139-143.

${ }^{87}$ García-Gallo, Manual de Historia del Derecho español, t. II, pp. 669-671; texto o fuente $n^{\circ} 868$ en la $9^{a}$ edición revisada que es la que cito en este artículo, como indico más adelante en la nota 107.

${ }^{88}$ Juan Manzano Manzano, Historia de las Recopilaciones de Indias, 2 volúmenes (volumen I, Siglo XVI; volumen II, Siglo XVII), Madrid, 1950-1956; 2a edición Madrid, 1981; 3ª edición Madrid, 1991.
} 
del derecho indiano, pero sí aludía a la situación normativa en la que estarían inicialmente las comunidades indígenas del llamado Nuevo Mundo, cuando señalaba que «las leyes castellanas, dictadas para un pueblo que había llegado a un grado avanzado de su evolución histórica, no podían ser aplicadas sin más ni más a otro pueblo extraño que apenas si se encontraba en los primeros pasos de su desenvolvimiento» ${ }^{89}$.

En 1967 publicaría don Juan Manzano el breve estudio monográfico titulado «Las leyes y costumbres indígenas en el orden de prelación de fuentes del Derecho indiano $\rangle^{90}$, en el cual abordaba ese aspecto concreto, tan importante y tan interesante, sobre la aplicación de los ordenamientos jurídicos autóctonos. Hacía allí la afirmación de que tales ordenamientos estarían integrados por «normas por regla general de carácter consuetudinario» ${ }^{91} \mathrm{e}$ indicaba que «cada nación o grupo indígena tenía sus normas (...), con arreglo a las cuales vivían estas comunidades prehispánicas hasta el momento en que fueron descubiertas por los españoles $\rangle^{92}$, para resolver o considerar después la cuestión del lugar que ocuparían en el orden de prelación de fuentes del derecho indiano mediante la previa equiparación de los ordenamientos jurídicos autóctonos con los fueros locales en el derecho de Castilla: «A estas leyes y costumbres de las diferentes comunidades indígenas el legislador español concedió el mismo valor que a los viejos fueros castellanos», y ello de tal manera que «algún famoso jurisconsulto de la época aplica a aquéllas la misma denominación que a éstas: fueros ${ }^{93}$, escribía el profesor Manzano aludiendo al licenciado Polo de Ondegardo.

Además de las aportaciones y las indicaciones mencionadas de Altamira y de Manzano, y aparte de los artículos y los estudios monográficos de García-Gallo a los cuales me refiero más adelante en el epígrafe 3,B del presente artículo, no es muy abundante la producción bibliográfica existente sobre la materia que constituye el objeto de estas páginas. Así, por ejemplo, en una pequeña monografía sobre los pleitos de indios, que fue publicada en el año 1945 por Pío Ballesteros ${ }^{94}$, su autor consideraba aplicables a las comunidades aborígenes no sólo sus normas jurídicas consuetudinarias de origen prehispánico, sino también los nuevos usos y costumbres introducidos y practicados por dichas comunidades con posterioridad a la inserción de las Indias en la órbita política de la monarquía española ${ }^{95}$. Y se podrían mencionar igualmente, por último, algunos trabajos sobre esta materia que fueron publicándose en España

\footnotetext{
${ }^{89}$ Manzano, Historia de las Recopilaciones de Indias, vol. I, p. 6.

${ }^{90}$ Juan Manzano Manzano, «Las leyes y costumbres indígenas en el orden de prelación de fuentes del Derecho indiano», en Revista del Instituto de Historia del Derecho "Ricardo Levene" núm. 18, Buenos Aires, 1967, pp. 65-71.

${ }^{91}$ Manzano, «Las leyes y costumbres indígenas en el orden de prelación de fuentes ...», p. 67.

${ }^{92}$ Manzano, «Las leyes y costumbres indígenas en el orden de prelación de fuentes ...», pp. 67-68.

${ }^{93}$ Manzano, «Las leyes y costumbres indígenas en el orden de prelación de fuentes ...», pp. 67-68.

${ }^{94}$ Pío Ballesteros, «Los indios y sus litigios según la Recopilación de 1680», en Revista de Indias núm. 22, Madrid, 1945, pp. 607-633.

${ }^{95}$ Ballesteros, «Los indios y sus litigios según la Recopilación de 1680», p. 619.
} 
en la década de los años setenta del siglo XX, muy poco tiempo después de la aparición de la Metodología de la Historia del Derecho indiano de García-Gallo.

En 1976 Carlos Díaz Rementería, en un trabajo sobre «La costumbre indígena en el Perú hispánico» ${ }^{96}$, en el cual estudiaba globalmente a ésta, «tanto la nacida en la época prehispánica como la desarrollada bajo la dominación castellana», pensaba que la costumbre autóctona, prehispánica a no, admitida como válida, constituía la primera fuente del derecho aplicable a los indios; y entre las supervivencias prehispánicas que advertía en el Perú de finales del siglo XVI y comienzos del siglo XVII se encontraba, por ejemplo, el quipocamayo, «que desarrollaba las funciones propias de un escribano» ${ }^{97}$. Y en 1977, en el libro titulado El cacique en el virreinato del $P e r u^{98}$, el mismo profesor Díaz Rementería afirmaba en relación con lo que más puede interesar acerca de esta materia que «se está reconociendo la existencia de unas costumbres a las que se reconoce pleno poder normativo» ${ }^{99}$, así como que «la actual historiografía jurídico-indiana ha coincidido unánimemente en hacer resaltar el valor de la costumbre como fuente del Derecho indiano en su vertiente indigenista» ${ }^{100}$.

También yo mismo, en su día, tuve ocasión de ocuparme de la cuestión del componente indígena o autóctono del ordenamiento jurídico indiano en la elaboración de mi tesis doctoral ${ }^{101}$, que me había sido sugerida por don Juan Manzano, quien —en la línea de su propio maestro, don Rafael Altamira - la dirigió, y que sería presentada en el año 1979. De mi tesis doctoral procedían varios artículos sobre esta materia que fueron apareciendo en diferentes revistas y que quedaron reunidos después en un volumen publicado en $1995^{102}$, y de los cuales quizá resulte oportuno citar aquí especialmente el titulado «El elemento indígena en la formación del Derecho indiano», de donde he tomado una parte de la información recogida ahora en estas páginas y que se publicaría en $1983^{103}$.

En ese año 1983, por cierto, el profesor Gibert - en cuya Historia general del derecho español del año 1968, como se indica en la nota 24 de este artículo, no había podido ocuparse del derecho indiano- consideró oportuno incluir en su Ciencia ju-

\footnotetext{
${ }^{96}$ Carlos Díaz Rementería, «La costumbre indígena en el Perú hispánico», en Anuario de Estudios Americanos núm. XXXIII, Sevilla, 1976, pp. 189-215.

${ }^{97}$ Díaz Rementería, «La costumbre indígena en el Perú hispánico», p. 214.

${ }^{98}$ Carlos Díaz Rementería, El cacique en el virreinato del Perú. Estudio histórico-jurídico, Sevilla, 1977.

${ }^{99}$ Díaz Rementería, El cacique en el virreinato del Perú. Estudio histórico-jurídico, p. 113, nota 2.

${ }^{100}$ Díaz Rementería, El cacique en el virreinato del Perú. Estudio histórico-jurídico, p. 112, nota 2.

${ }^{101}$ Miguel Ángel González de San Segundo, Derecho prehispánico e instituciones indígenas en el ordenamiento jurídico indiano (Notas para su estudio), Facultad de Derecho, Universidad Complutense de Madrid, curso académico 1979-1980. Tesis doctoral publicada por la Editorial de la Universidad Complutense de Madrid, Servicio de Reprografía, Madrid, 1980.

${ }^{102}$ Miguel Ángel González de San Segundo, Un mestizaje jurídico: El Derecho indiano de los indígenas (Estudios de Historia del Derecho), Madrid, 1995.

${ }^{103}$ González de San Segundo, «El elemento indígena en la formación del Derecho indiano», en Revista de Historia del Derecho núm. 11, Buenos Aires, 1983, pp. 401-453, citado ya en la nota 83 de este artículo.
} 
rídica española una breve referencia al jurista hispano-peruano Polo de Ondegardo, mencionando «su relación acerca del Daño que resulta de no guardar a los indios sus fueros» ${ }^{104}$. Creo, para ser más exactos, que el título correcto o completo de esa obra, fechada el 26 de junio de 1571 y bien conocida por los historiadores del derecho indiano, era Relación de los fundamentos acerca del notable daño que resulta de no guardar a los indios sus fueros ${ }^{105}$.

\section{El componente indígena del derecho indiano en las exposiciones de con- junto y en los artículos y estudios monográficos del profesor García-Gallo}

En relación con la materia del componente indígena del derecho indiano en la obra del profesor Alfonso García-Gallo, menciono seguidamente dos de sus exposiciones de conjunto: por una parte, el Manual de Historia del Derecho español del año 1934, en colaboración con Román Riaza ${ }^{106}$, y, por otra parte, el Manual de Historia del Derecho español aparecido en los años 1959-1962, con numerosas ediciones posteriores ${ }^{107}$; y me refiero también, a continuación, tanto a la varias veces citada Metodología de la Historia del Derecho indiano, del año 1970, como a sus diversos artículos y estudios monográficos, publicados en diferentes revistas y actas de congresos y que fueron reunidos después en tres volúmenes de los años $1972^{108}, 1982^{109}$ y $1987^{110}$.

\section{A) El componente indígena del derecho indiano en las exposiciones de con- junto de García-Gallo}

Me ocupo en primer término del Manual de Historia del Derecho español publicado en el año 1934, conjuntamente, por Román Riaza y Alfonso García-Gallo, en el cual se indicaba que, «dentro de una orientación común, cada parte ha sido redactada por separado» ${ }^{11}$. La autoría de los parágrafos a los que me refiero seguidamente co-

\footnotetext{
${ }^{104}$ Rafael Gibert, Ciencia jurídica española, Granada, 1983, p. 19.

${ }^{105}$ González de San Segundo, «El elemento indígena en la formación del Derecho indiano», p. 427, nota 59.

${ }^{106}$ Riaza y García-Gallo, Manual de Historia del Derecho español, Madrid, 1934, citado en la nota 20 de este artículo.

${ }^{107}$ García-Gallo, Manual de Historia del Derecho español, 2 volúmenes, Madrid, 1959-1962, citado en la nota 22 de este artículo. Lo cito en esta ocasión por la $9^{a}$ edición revisada, Madrid, 1982, en cuya página VIII se incluía la «Advertencia sobre la segunda edición» (del año 1964), la «Advertencia sobre la cuarta edición» (del año 1971) y la «Advertencia sobre la sexta edición» (del año 1975), en relación con las correcciones, modificaciones y adiciones llevadas a cabo sucesivamente.

${ }^{108}$ Alfonso García-Gallo, Estudios de Historia del Derecho indiano, Madrid, 1972.

${ }^{109}$ Alfonso García-Gallo, Estudios de Historia del Derecho privado, Sevilla, 1982.

${ }^{110}$ Alfonso García-Gallo, Los orígenes españoles de las Instituciones americanas. Estudios de Derecho indiano, Madrid, 1987.

${ }^{111}$ Riaza y García-Gallo, Manual de Historia del Derecho español, «Prólogo», p. X.
} 
rrespondía a García-Gallo, de conformidad con la explicación que se daba en relación con las partes redactadas por cada uno de los dos coautores ${ }^{112}$.

En el parágrafo $\mathrm{n}^{\circ} 471$, titulado «La influencia del Derecho indígena americano», hacía García-Gallo el planteamiento general de que en el ordenamiento jurídico indiano se tuvo en cuenta el derecho consuetudinario indígena, así como las afirmaciones de que la costumbre, indígena o no, servía de norma, y de que esa costumbre influyó en la legislación dada para las Indias. En este sentido, escribía García-Gallo en 1934 lo siguiente: «Al conquistarse América se dió para aquellos territorios un Derecho propio, adaptado a sus necesidades, del cual el [derecho] castellano era a la vez inspirador y supletorio. Para esta adaptación se tuvieron en cuenta el Derecho consuetudinario indígena americano, las condiciones geográficas, económicas, sociales y políticas del país para [el] que se legislaba. Pero aún, a pesar de todo ello, las disposiciones resultaban con mucha frecuencia inaplicables, porque, caso de llevarse a la práctica, producían males mayores que los que se trataba de remediar. En vista de ello se llegó incluso a autorizar a los virreyes y Audiencias su no ejecución; en estos casos era la costumbre, indígena o no, la que servía de norma. Esta costumbre se recogía muchas veces en disposiciones posteriores, de forma que la legislación dada para las Indias estuvo influida por ella en una medida mucho mayor de lo que se ha creído hasta ahora ${ }^{113}$.

Y, por otra parte, el parágrafo $n^{\circ} 502$, sobre «El municipio bajo los Reyes Católicos y la casa de Austria», contenía, en relación con el componente indígena del derecho indiano, por ejemplo, las indicaciones de que en los pueblos de indios «se mantenía la autoridad de los caciques, que se transmitía de padres a hijos», y de que «los $c a$ ciques, como señores naturales de los indios, se encontraban al frente de los pueblos de éstos» ${ }^{114}$.

Me refiero ahora, en segundo lugar, al Manual de Historia del Derecho español publicado por don Alfonso García-Gallo a partir de los años 1959-1962. En el tomo primero, volumen subtitulado El origen y la evolución del Derecho, eran varios los parágrafos de interés para el conocimiento de la materia del componente indígena del ordenamiento jurídico indiano. Así, en el parágrafo $n^{\circ} 216$, titulado «Los elementos integrantes del Derecho indiano», hacía García-Gallo, después de enumerar los otros componentes, esta afirmación: «Finalmente, junto al Derecho indiano español,

\footnotetext{
${ }^{112} \mathrm{La}$ indicación que los dos coautores hacían al respecto era la siguiente: «A R. Riaza se deben la Introducción, las fuentes desde la época visigoda hasta el siglo XIX - con excepción de las musulmanas y de la bibliografía - y toda la segunda parte ( $\S$ 1-33, 152-181, 293-297, 299-304, 306-309, 311-315, 393-395, 397-399, 401-412, 414-415, 417-418, 473-475, 477-483, 485-486, 527-531 y 538-698); a A. García Gallo la primera parte, con excepción de aquellas fuentes (§§ 34-51, 182-292, 298, 305, 310, 316-392, 396, 400, 413, 416, 419-472, 476, 487-526, 532-537), y los índices». Riaza y García-Gallo, Manual de Historia del Derecho español, «Prólogo», p. X.

${ }^{113}$ Riaza y García-Gallo, Manual de Historia del Derecho español, p. 472.

${ }^{114}$ Riaza y García-Gallo, Manual de Historia del Derecho español, p. 561.
} 
en sus diferentes aspectos, rigieron los Derechos consuetudinarios indígenas sobre la población autóctona, expresamente reconocidos como vigentes por las leyes españolas, salvo en aquello [en] que estuviesen en contradicción con el Derecho natural o con las leyes indianas de carácter general $\gg^{115}$.

En el parágrafo $\mathrm{n}^{\circ} 577$, sobre «La doctrina de los juristas» en relación con la ignorancia del derecho, indicaba García-Gallo que a los indios americanos «se les permite vivir conforme s sus propias costumbres» ${ }^{116} ; \mathrm{y}$ al ocuparse de las fuentes del derecho en Indias, en el parágrafo $\mathrm{n}^{\circ} 777$, titulado «El orden legal de aplicación de las fuentes», explicaba que «sin embargo de esta aplicación del Derecho castellano, y en atención al grado de cultura de los indios, que les impide conocer las leyes españolas, la propia legislación de Indias desde 1555 les permite regirse por sus viejas costumbres o por las leyes y costumbres que de nuevo ellos mismos establezcan, en tanto no se opongan a la religión y, desde 1680 , tampoco a la Recopilación ${ }^{117}$.

De los parágrafos 1275 a 1292, dedicados a «La república de los indios», resulta especialmente interesante el parágrafo $\mathrm{n}^{\mathrm{0}} 1280$, sobre «La condición jurídica de los indios», que contenía la afirmación de que «así, se les permite que se rijan por sus propias costumbres en cuando no se opongan a la religión y a las leyes reales», y la de que «no se ventilan sus pleitos por la complicada legislación española, sino en forma breve y sumaria por jueces indígenas y conforme a sus costumbres» ${ }^{118}$.

Y en el parágrafo $\mathrm{n}^{\circ} 1292$ bis — que es básico en relación con la materia que constituye el objeto de estas páginas, pero del que en este momento no sé en cuál de las ediciones del Manual de García-Gallo fue incorporado - sobre la «Pervivencia» de la organización «política» indígena en el ordenamiento jurídico indiano, explicaba que «se reconoce y acepta por todas partes la estructura y organización de los grupos inferiores, porque gracias a ella la población indígena se mantiene encuadrada y se facilita su gobierno. Así, p. ej., los repartimientos se hacen encomendando a los caciques con sus indios»; que «de este modo se mantienen las comunidades indigenas (...) con sus bienes propios y sus autoridades, designadas estas como caciques (...), señores o principales de los indios»; que «la organización indígena se sigue respetando: los cacicazgos se proveen conforme al Derecho indígena por sucesión o elección (...), los tributos se fijan y perciben conforme a aquel [el derecho indígena], etcétera»; y que «del mismo modo, se conservan otras formas de organización indígena, como es en el Perú la mita 'turno' para la prestación de servicios personales, o los tambos 'mesones' en los caminos»"119.

En cuanto al tomo segundo de este Manual de Historia del Derecho español del profesor García-Gallo, volumen subtitulado Metodología histórico-jurídica y Anto-

\footnotetext{
${ }^{115}$ García-Gallo, Manual de Historia del Derecho español, t. I, p. 104.

${ }^{116}$ García-Gallo, Manual de Historia del Derecho español, t. I, p. 299.

${ }^{117}$ García-Gallo, Manual de Historia del Derecho español, t. I, p. 417.

${ }^{118}$ García-Gallo, Manual de Historia del Derecho español, t. I, p. 722.

${ }^{119}$ García-Gallo, Manual de Historia del Derecho español, t. I, p. 734.
} 
logía de fuentes del antiguo Derecho español, creo que se ha de mencionar muy especialmente el texto o la fuente $\mathrm{n}^{\circ} 348$, consistente en la publicación, a doble columna, de la Real Cédula dirigida por Carlos V a los caciques indios de la Verapaz, a petición de los mismos, del 6 de agosto de 1555, en la columna primera, y de la ley 2,1,4 de la Recopilación de Indias, «Que se guarden las leyes que los indios tenían antiguamente para su gobierno, y las que se hicieren de nuevo», formada a base de dicha real cédula del emperador don Carlos y la princesa doña Juana, gobernadora, dada en Valladolid a 6 de agosto de $1555^{120}$, en la columna segunda. Esas mismas disposiciones - que son, sin duda, fundamentales en relación con la materia del componente indígena del derecho indiano - se han reproducido igualmente, después, en otras antologías o colecciones de textos histórico-jurídicos, con finalidad docente, por diversos profesores de nuestra disciplina.

Queda mencionado ya más arriba el texto o la fuente $\mathrm{n}^{\mathrm{o}} 868$ de esta Antología, donde García-Gallo incluía la Carta de Carlos V a los reyes y repúblicas de las Indias Orientales, solicitando su amistad y colaboración, fechada en Barcelona el 1 de mayo de 1543 y cuyos destinatarios eran «los reyes, príncipes y señores, repúblicas y comunidades de todas las provincias, tierras e islas que están al mediodía y al poniente de la Nueva España» ${ }^{121}$.

$\mathrm{Y}$, entre otros varios ejemplos más que cabría señalar, tiene también particular importancia el texto o la fuente $\mathrm{n}^{\circ} 957$, correspondiente a las Leyes Nuevas de Indias, de 20 de noviembre de 1542 , en cuya ley 20 se ordenaba a las audiencias y a los jueces inferiores la aplicación de los «usos y costumbres» de las comunidades indígenas, con estas palabras reproducidas en la Antología de García-Gallo: «que no den lugar a que en los pleitos entre indios o con ellos se hagan proçessos ordinarios ni aya alargas, como suele acontesçer por la maliçia de algunos abogados y procuradores, sino que sumariamente sean determinados, guardando sus usos y costumbres, no siendo claramente injustos, y que tengan las dichas abdiençias cuidado que así se guarde por los otros juezes inferiores» ${ }^{122}$.

Por lo que se refiere a la Metodología de la Historia del Derecho indiano del año 1970, tantas veces citada en este artículo, son abundantes los parágrafos dedicados por García-Gallo a la materia del componente indígena. En el parágrafo ${ }^{\circ} 9$, titulado «Sentido territorial de la expresión [indiano]», señalaba que «si como Derecho indiano se considera el vigente en las Indias occidentales y orientales, es claro que dentro de él hay que incluir no sólo el Derecho castellano trasplantado al Nuevo Mundo o el establecido por España especialmente para él, sino también cualquier otro que haya tenido vigencia en aquellas partes; es decir, tanto el Derecho de los indios o po-

\footnotetext{
${ }^{120}$ García-Gallo, Manual de Historia del Derecho español, t. II, pp. 234-235.

${ }^{121}$ García-Gallo, Manual de Historia del Derecho español, t. II, pp. 669-671, texto citado ya en la nota 86 de este artículo.

${ }^{122}$ García-Gallo, Manual de Historia del Derecho español, t. II, pp. 776-777.
} 
blaciones autóctonas como, en su caso, de los grupos alienígenas allí establecidos (v. gr., los negros) que conserven sus costumbres entre ellos»; y concluía indicando que, en nuestros estudios histórico-jurídicos, el término «indiano, sin embargo, no se ha solido entender así» ${ }^{123}$.

En el parágrafo $\mathrm{n}^{\circ} 11$, titulado «El Derecho indígena», se hacían las importantes afirmaciones de que «este Derecho [el Derecho indígena] no rige sólo en la época prehispánica. Perdura y continúa rigiendo, aunque a veces parcialmente y desarticulado, después de aquélla [después de la época prehispánica], bajo el dominio español y en no pocos aspectos llega hasta nuestros días»; de que «el Derecho hispánico y el indígena coexisten, rigiendo aquél a los españoles y en parte a los indios, y éste a los últimos; pero no como sistemas radicalmente aislados, sino comunicantes»; y de que «hay un mestizaje jurídico, como lo hay racial, especialmente en los ambientes populares, que es del más alto interés conocer. Desgraciadamente, los estudiosos americanos apenas se han ocupado de él, contemplando lo indígena tan sólo en su fase prehispánica» $^{124}$.

En el parágrafo $\mathrm{n}^{\circ} 12$, acerca de «Las costumbres de la población negra», escribía García-Gallo que «la vigencia de su propio Derecho, aunque reducido a concepciones jurídicas y normas aisladas, se encuentra también en los grupos de población negra allí donde éstos ofrecen cierta densidad y homogeneidad»; con la salvedad o la peculiaridad siguiente: «Aunque también aquí las viejas costumbres sufren el influjo del Derecho español y aun del [Derecho] indígena» ${ }^{125}$.

En el parágrafo $\mathrm{n}^{\circ} 181$, titulado «Actos y comportamientos», en relación con el derecho no escrito, advertía que «en los pleitos mercantiles y en los de indios se huye expresamente de la forma escrita. No de todo queda constancia documental. Resulta por ello evidente que todos esos actos o comportamientos de la vida jurídica son sumamente reveladores de ésta y, en cuanto pueden ser captados por nosotros, constituyen preciosas fuentes de conocimiento de carácter jurídico. La dificultad radica en llegar a conocerlos» ${ }^{126}$.

En el parágrafo ${ }^{\circ} 201$, sobre «Los autores» de las «fuentes históricas y narrativas», afirmaba que «la casi totalidad de estas historias han sido escritas por españoles y ofrecen por tanto, inevitablemente, una visión hispánica de la vida americana. Algunas, han sido escritas por españoles recogiendo precisamente información indígena, como la de Sarmiento de Gamboa sobre los incas o la de Bernardino de Sahagún sobre los mexicanos. Alguna ha sido obra de un mestizo, que aún recogiendo la tradición indígena no olvida que lleva sangre española: como el Inca Garcilaso. Pero no faltan tampoco algunas, aunque poco numerosas, que ofrecen la versión de los

\footnotetext{
${ }^{123}$ García-Gallo, Metodología de la Historia del Derecho indiano, pp. 18-19.

${ }^{124}$ García-Gallo, Metodología de la Historia del Derecho indiano, p. 20.

${ }^{125}$ García-Gallo, Metodología de la Historia del Derecho indiano, p. 20.

${ }^{126}$ García-Gallo, Metodología de la Historia del Derecho indiano, p. 107.
} 
vencidos: tal la Nueva Crónica de Guaman Poma de Ayala o algunas otras de la Nueva España»; y concluía afirmando que «esto, naturalmente, ofrece una doble visión de los problemas que la hace ganar en profundidad ${ }^{127}$.

En el parágrafo $\mathrm{n}^{\circ} 248$, titulado «El planteamiento inicial del tema» (dentro de la fase inicial de la investigación, la elección de tema), el profesor García-Gallo mencionaba expresamente, a título de ejemplo, la importante cuestión de «si las costumbres indígenas han influido o no en las leyes españolas $\rangle^{128}$.

$\mathrm{Y}$ en el parágrafo $\mathrm{n}^{\circ} 316$, sobre «El estudio de los sistemas indígenas y negros», en relación con el «sistema jurídico de la institución» que sea objeto de investigación, escribía que «si el investigador, dando a su estudio toda la amplitud necesaria, abarcara también dentro de lo indiano las costumbres jurídico-indígenas o de los grupos de población negra — no en cuanto prehispánicas, sino como coexistentes con el Derecho español - estaría justificado su tratamiento por separado, porque en realidad constituyen sistemas propios»; que, «aun en ese caso, si el estudio no se orienta hacia el conceptualismo y el dogmatismo de un sistema sino hacia la normatividad de las situaciones y relaciones sociales, cabría presentar unas junto a otras las normas que rigen entre los españoles, las que rigen entre los indios y negros», y ello «máxime si se tiene en cuenta que estos dos últimos, aunque conservan sus propias formas de ordenación, experimentan al mismo tiempo un proceso de aculturación que les hace asimilar, con más o menos fidelidad, no pocos principios del Derecho español» ${ }^{129}$.

\section{B) El componente indígena del derecho indiano en los artículos y estudios monográficos de García-Gallo}

Aparte de la indicada exposición de conjunto del año 1934, en colaboración con Román Riaza, y del Manual de Historia del Derecho español de los años 1959-1962 y con numerosas ediciones posteriores, y además de la tantas veces citada Metodología de la Historia del Derecho indiano del año 1970, el profesor García-Gallo explicaba o recordaba diversos aspectos de la existencia de un componente o elemento indígena dentro del ordenamiento jurídico indiano en muchos de sus numerosos artículos y estudios monográficos publicados a lo largo de más de tres décadas. Los que menciono seguidamente, según el orden cronológico de su aparición, se sitúan entre los años 1946 y 1977.

En 1946 publicó García-Gallo el trabajo titulado «El proyecto de "Código peruano" de Gaspar de Escalona y Agüero» ${ }^{130}$, en el cual indicaba que «la idea de poner

\footnotetext{
${ }^{127}$ García-Gallo, Metodología de la Historia del Derecho indiano, p. 116.

${ }^{128}$ García-Gallo, Metodología de la Historia del Derecho indiano, p. 135.

${ }^{129}$ García-Gallo, Metodología de la Historia del Derecho indiano, p. 174.

${ }^{130}$ García-Gallo, «El proyecto de "Código peruano" de Gaspar de Escalona y Agüero», en Anuario de Historia del Derecho Español núm. 17, Madrid, 1946, y en sus Estudios de Historia del Derecho indiano, Madrid, 1972, pp. 367-399. Cito aquí por estos Estudios.
} 
las leyes españolas al alcance de los indios no era desde luego nueva, pues ya en los primeros momentos se había observado la dificultad que éstos encontraban en entenderlas. Así, en 1535, el Lcdo. Vasco de Quiroga había señalado que las leyes dictadas para los indios debían ser pocas, claras, conforme a su calidad, manera y condición y capacidad y simplicidad que ellos pudiesen saber y comprender» ${ }^{131}$. En 1951-1952 apareció su estudio sobre «La ley como fuente del Derecho en Indias en el siglo $\mathrm{XVI} »^{132}$, que desde luego planteaba «sin desconocer la importancia de la costumbre como fuente del Derecho en Indias» ${ }^{133}$. Y en 1952 describía el «Panorama actual de los estudios de Historia del Derecho indiano» ${ }^{134}$, haciendo notar que, a causa de la tendencia existente en buena parte de los cultivadores de nuestra disciplina, era posible considerar el ámbito de algunos de sus trabajos «demasiado ceñido a las leyes dictadas por los reyes» ${ }^{135}$.

En 1955, en su estudio sobre «El Derecho común ante el Nuevo Mundo»» ${ }^{136}$, se refería García-Gallo a la «coexistencia de dos o más sistemas jurídicos, el español y los indígenas», y en relación con ello explicaba que «los indios quedaron obligados a las leyes generales que expresamente les afectaban, con lo cual vino a reconocerse, por encima del sistema de personalidad, la vigencia general de los principios del Derecho español, como de un Derecho que indios y españoles habían de acatar» ${ }^{137}$; si bien, por otra parte, afirmaba que «se extremaron las cautelas en el trato con los indios, se proclamó una y otra vez su libertad, se reconoció la autoridad de los caciques» ${ }^{138}$.

En 1964, en el artículo titulado "Génesis y desarrollo del Derecho indiano» ${ }^{139}$, García-Gallo recordaba que «a los indios se les deja regirse por sus costumbres y, por tanto, el Derecho indígena convive con el [derecho] castellano»; sin perjuicio de lo cual, explicaba que «cuando los indios tratan con los españoles es el Derecho de éstos el que prevalece» ${ }^{140}$.

\footnotetext{
${ }^{131}$ García-Gallo, «El proyecto de "Código peruano" de Gaspar de Escalona y Agüero», p. 374.

${ }^{132}$ García-Gallo, «La ley como fuente del Derecho en Indias en el siglo XVI», en Anuario de Historia del Derecho Español núm. 21-22, Madrid, 1951-1952, pp. 607-730, y en sus Estudios de Historia del Derecho indiano, pp. 169-265. Cito aquí por estos Estudios.

${ }^{133}$ García-Gallo, «La ley como fuente del Derecho en Indias en el siglo XVI», p. 171.

${ }^{134}$ García-Gallo, «Panorama actual de los estudios de Historia del Derecho indiano», en Revista de la Universidad de Madrid, núm. 1, 1952, pp. 41-64. Artículo publicado también en sus Estudios de Historia del Derecho indiano, Madrid, 1972.

${ }^{135}$ García-Gallo, «Panorama actual de los estudios de Historia del Derecho indiano», p. 60.

${ }^{136}$ García-Gallo, «El Derecho común ante el Nuevo Mundo», en Revista de Estudios Políticos núm. 80, Madrid, 1955, pp. 133-152, y en sus Estudios de Historia del Derecho indiano, pp. 147-166. Cito aquí por estos Estudios.

${ }^{137}$ García-Gallo, «El Derecho común ante el Nuevo Mundo», p. 154.

${ }^{138}$ García-Gallo, «El Derecho común ante el Nuevo Mundo», p. 160.

${ }^{139}$ García-Gallo, «Génesis y desarrollo del Derecho indiano», en la revista Atlántida, Madrid, 1964, pp. 339-359, y en sus Estudios de Historia del Derecho indiano, pp. 123-145. Cito aquí por estos Estudios. ${ }^{140}$ García-Gallo, «Génesis y desarrollo del Derecho indiano», p. 125.
} 
En 1967, al estudiar los «Problemas metodológicos de la Historia del Derecho indiano» ${ }^{141}$, exponía García-Gallo la situación de los ordenamientos jurídicos autóctonos, afirmando categóricamente que «si como indiano queremos designar el Derecho vigente en Indias, entonces éste abarca tanto aquellas leyes especiales [se refería a las leyes integrantes de la "nueva legislación peculiar de las Indias"] como las [leyes] de Castilla o cualesquiera otras fuentes que rijan en la América española, incluso las costumbres indígenas» ${ }^{142}$; y que «como Derecho especial de las Indias hay que considerar también el indígena —o más propiamente los Derechos indígenas-, cuya importancia es evidente», en relación con lo cual decía que «es un problema que está por estudiar ${ }^{143}$. Y, acerca del papel o de la importancia de la costumbre en el ordenamiento jurídico indiano, señalaba claramente que «la costumbre es fuente del Derecho en Indias, como lo es en España», pero que «nada, en cambio, se dice sobre la costumbre en el inmenso campo del Derecho indiano», lo cual sería, más bien, una «prueba indirecta del reconocimiento de su vigencia, sin perjuicio de que se controle su contenido», puesto que «el Derecho consuetudinario no se ha enfrentado con la ley», sino que «ha coexistido con ella» ${ }^{144}$.

En 1973, en el artículo titulado «Bases para una programación de la enseñanza de la Historia del Derecho, y en especial de la del Derecho indiano» ${ }^{145}$, García-Gallo indicaba que «el Derecho o [las] costumbres indígenas suelen ser estudiados como algo anterior a la dominación española, como un sistema prehispánico»; pero que era un sistema que, sin embargo, «continúa rigiendo bajo el dominio español» ${ }^{146}$.

En 1974, en su estudio sobre «La ciencia jurídica en la formación del Derecho hispano-americano en los siglos XVI al XVIII ${ }^{147}$, señalaba García-Gallo que «la re-

\footnotetext{
${ }^{141}$ García-Gallo, «Problemas metodológicos de la Historia del Derecho indiano», en Revista del Instituto de Historia del Derecho "Ricardo Levene" núm. 18, Buenos Aires, 1967, pp. 13-64. Artículo publicado también en sus Estudios de Historia del Derecho indiano. Cito aquí por estos Estudios.

${ }^{142}$ García-Gallo, «Problemas metodológicos de la Historia del Derecho indiano», p. 73.

${ }^{143}$ García-Gallo, «Problemas metodológicos de la Historia del Derecho indiano», p. 92. En el mismo número del año 1967 de la revista argentina en la que apareció la primera edición de este artículo del profesor García-Gallo, por cierto, publicaba el profesor Manzano su estudio sobre el lugar que los ordenamientos jurídicos autóctonos habrían ocupado en el orden de prelación de fuentes del derecho indiano, cuyo planteamiento o cuyo punto de vista — como se señala en otro lugar de estas páginas - fue tenido en cuenta e incorporado muy poco tiempo después por el profesor Lalinde Abadía en su exposición de conjunto del año 1970 y por el profesor Tomás y Valiente en su Manual del año 1979; Manzano, «Las leyes y costumbres indígenas en el orden de prelación de fuentes del Derecho indiano», citado en la nota 90 del presente artículo.

${ }^{144}$ García-Gallo, «Problemas metodológicos de la Historia del Derecho indiano», pp. 104-105.

${ }^{145}$ García-Gallo, «Bases para una programación de la enseñanza de la Historia del Derecho, y en especial de la del Derecho indiano», en III Congreso del Instituto Internacional de Historia del Derecho Indiano, Madrid, 1973, pp. 1.107-1.130. Artículo publicado también en su libro Los orígenes españoles de las instituciones americanas. Estudios de Derecho indiano, Madrid, 1987, pp. 1.069-1.092.

${ }^{146}$ García-Gallo, «Bases para una programación de la enseñanza de la Historia del Derecho, y en especial de la del Derecho indiano», pp. 1.117-1.118.
} 
alidad muestra implacable la incapacidad de hecho que [los indígenas] padecen para vivir al modo de los españoles. Por ello, los juristas les dan la condición de menores o miserables que el Derecho romano atribuía a las gentes que por su rusticidad no podían equipararse a los ciudadanos normales, y con ello el disfrute de todos los privilegios inherentes a los mismos» ${ }^{148}$.

Me refiero seguidamente a un artículo que García-Gallo publicó primero con el título de «La penetración de los Derechos europeos y el pluralismo jurídico en la América española, 1492-1824» en $1975^{149}$ y después en $1976^{150}$, y que sería publicado otra vez en sus Estudios del año 1987 con el título, abreviado, de «El pluralismo jurídico en la América española, 1492-1824» ${ }^{151}$. Se trataba de una breve visión o exposición de síntesis, sin notas a pie de página, pero desde luego del mayor interés y de la mayor importancia en relación con la materia del componente indígena del derecho indiano.

En dicho artículo exponía, por una parte, que a las comunidades indígenas «desde mediados del siglo XVI se las permite regirse por sus propias costumbres en cuanto no se opongan a la ley natural o a la religión católica», y que «coexisten en todas las regiones de Indias tres sistemas jurídicos diferentes: el castellano-indiano, el canónico y el indígena»; que «los Derechos indígenas, distintos en cada pueblo, gozan de un amplio campo de aplicación», y que «son plenamente consuetudinarios, pues incluso las leyes que en algunos se atribuyen a sus antiguos reyes no se encuentran escritas y solo se recuerdan por tradición»; que «estas costumbres en muchos casos son recogidas y expuestas por escrito por los misioneros y aun por algunos juristas españoles; por éstos, con el fin de conocer y acomodar a ellas la actuación del gobierno sobre los indios. No faltan españoles que elogian muchas de estas costumbres», y que «la coexistencia de diversos sistemas jurídicos en un mismo territorio de América determina influencias recíprocas entre ellos, aunque en muy desigual medida» ${ }^{152}$.

\footnotetext{
${ }^{147}$ García-Gallo, «La ciencia jurídica en la formación del Derecho hispano-americano en los siglos XVI al XVIII», en Atti del Terzo Congresso Internazionale della Società Italiana di Storia del Diritto (1973), Florencia, 1974, pp. 317-353; en Anuario de Historia del Derecho Español núm. 44, Madrid, 1974, pp. 157-200 (por donde lo cito en esta ocasión), y en su libro Los orígenes españoles de las instituciones americanas. Estudios de Derecho indiano, pp. 257-297.

${ }^{148}$ García-Gallo, «La ciencia jurídica en la formación del Derecho hispano-americano en los siglos XVI al XVIII», p. 179.

${ }^{149}$ García-Gallo, «La penetración de los Derechos europeos y el pluralismo jurídico en la América española, 1492-1824», en XIV International Congress of Historical Sciences. San Francisco. August 2129 1975, San Francisco, 1975, pp. 5-19.

${ }^{150}$ García-Gallo, «La penetración de los Derechos europeos y el pluralismo jurídico en la América española, 1492-1824», en Index. Quaderni camerti di studi romanistici. International Survey of Roman Law, tomo. VI, Nápoles, 1976, pp. 3-11.

${ }^{151}$ García-Gallo, «El pluralismo jurídico en la América española, 1492-1824», en su libro Los orígenes españoles de las Instituciones americanas. Estudios de Derecho indiano, pp. 299-310, por donde lo cito en este trabajo.

${ }^{152}$ García-Gallo, «El pluralismo jurídico en la América española, 1492-1824», pp. 305 y 306.
} 
Por otro lado, García-Gallo explicaba que «la política de civilizar a los indios, aunque se haya permitido a estos regirse por sus costumbres, tiende a su españolización cultural y jurídica»; que «la convivencia de los pueblos determina no sólo un mestizaje racial, sino también uno cultural, haya o no mezcla de sangres», y que «en todo caso, siendo los Derechos indígenas consuetudinarios, faltan fuentes escritas directas sobre los cambios que en ellos se han podido efectuar. Es necesario acudir a los antiguos informes de misioneros, autoridades o viajeros y a documentos públicos o privados que ocasionalmente recogen actos realizados por los indios. Pero este estudio, sin duda dificultoso, no se ha realizado» ${ }^{153}$.

Finalmente, García-Gallo se refería en este artículo a algunas manifestaciones concretas del componente indígena del derecho indiano y de la pervivencia de la organización aborigen, afirmando que «en una apreciación general, sabemos que toda la organización política indígena ha sido desconocida o conscientemente destruída al implantar la castellana. (...). Toda participación de los indios, cualquiera que sea su clase, en el gobierno superior, desaparece. Sólo subsiste, a lo sumo, el escalón inferior de esta organización, a nivel de los cacicazgos»; que «los pueblos o aldeas indígenas han conservado en muchas partes su vieja organización, pero en otras al ser concentrados en reducciones la han visto sustituida por otra de tipo español»; que «en el orden patrimonial los indios han conservado su propio régimen, respetado por el Derecho indiano»; que «la transmisión de bienes entre los indios, incluso por causa de muerte, se efectúa también de acuerdo con sus costumbres», y que «la aplicación de la costumbre indígena se fortalece en los casos conflictivos en que llegando a pleito éste se resuelve, en casos poco importantes, por las autoridades indígenas», si bien - concluía - «el carácter oral de este procedimiento impide que dispongamos de las fuentes necesarias para estudiar la situación» ${ }^{154}$.

Y en 1977, en el trabajo titulado «La condición jurídica del indio» ${ }^{155}$, al referirse a la colonización iniciada en las Antillas y a la compatibilidad de la libertad de los indígenas con el trabajo obligatorio de los mismos, recordaba García-Gallo, por ejemplo, que «no sólo se mantuvieron los repartimientos, sino que se generalizaron, adscribiendo los caciques con sus indios a los españoles para que trabajaran para éstos en sus campos y en las minas»; escribía igualmente que, en un momento posterior, «se insistió (...) en la obligación de los indios, como la de todo súbdito aun de condición libre, (...) de pagar un tributo personal al rey, como lo habían pagado a sus caciques o autoridades antes de la conquista»; y todo ello, en fin, «distinguiendo desde mediados del siglo XVI la república de los indios de la república de los espa-

\footnotetext{
${ }^{153}$ García-Gallo, «El pluralismo jurídico en la América española, 1492-1824», pp. 307 y 308.

${ }^{154}$ García-Gallo, «El pluralismo jurídico en la América española, 1492-1824», p. 309.

${ }^{155}$ García-Gallo, «La condición jurídica del indio», en Miguel Rivera Dorado (editor), Antropología de España y América, Madrid, 1977, pp. 281-292; en sus Estudios de Historia del Derecho privado, Sevilla, 1982, pp. 167-177, y en su libro Los orígenes españoles de las Instituciones americanas. Estudios de Derecho indiano, pp. 743-756 (por donde lo cito en esta ocasión).
} 
ñoles, y admitiendo que los de aquélla se rigieran por sus propias costumbres en tanto éstas no fueran contrarias al Derecho natural (...) y a la religión cristiana» ${ }^{156}$. Se trataba, pues, de distintos e importantes aspectos de la presencia o del mantenimiento de un componente indígena o autóctono en el ordenamiento jurídico indiano.

\section{C) La Memoria de la oposición de García-Gallo a la cátedra de Historia del Derecho (1935) y su Programa de Historia del Derecho indiano (1944-1981)}

Termino ya la exposición de la materia tratada en estas páginas, haciendo dos breves referencias finales: por una parte, a la Memoria de la oposición de don Alfonso García-Gallo a la cátedra de Historia del Derecho, la cual obtuvo en 1935; y, por otra parte, a su Programa de Historia del Derecho indiano, que fue el esquema o la base de sus explicaciones docentes de esa asignatura a lo largo de muchos años.

El desarrollo y las circunstancias de la oposición del profesor García-Gallo a la cátedra de Historia del Derecho de la Universidad de Murcia, celebrada en el mes de junio del citado año 1935, han sido objeto de estudio por parte de su último discípulo directo, el profesor Sánchez-Arcilla, en el Homenaje de la Universidad Complutense de Madrid que fue publicado en $1996^{157}$. En relación con la Memoria presentada en dicha oposición y expuesta reglamentariamente en el segundo ejercicio de la misma $^{158}$, ha escrito Sánchez-Arcilla — citando a García-Gallo- sobre la materia de referencia en este artículo, lo siguiente: «Respecto a los derechos indígenas americanos, sólo interesarían al historiador del derecho español en la medida en que hayan podido influir en el Derecho indiano emanado de la metrópoli o de las autoridades españolas en América, "pues no se trata de un Derecho español" $\gg$ "

Lo que García-Gallo exponía, concretamente, era que «el hecho de darse en un territorio que se ha incorporado a España no es motivo para estudiarlo en la historia de nuestro derecho; en este caso habría que estudiar el italiano, el francés, belga, filipino, etcétera, vigente en cada uno de los países anexionados $\rangle^{160}$. Pero, al menos en ese párrafo de su Memoria del año 1935, creo que no entraba propiamente en la cuestión del componente indígena del derecho indiano, puesto que, al afirmar sobre los ordenamientos jurídicos indígenas o autóctonos —o más bien de origen indígena, me parece que habría que entender- que «no se trata de un Derecho español», pienso

\footnotetext{
${ }^{156}$ García-Gallo, «La condición jurídica del indio», pp. 748, 751 y 752, respectivamente.

${ }^{157}$ José Sánchez-Arcilla Bernal, «Las oposiciones a cátedra de don Alfonso García-Gallo», en Homenaje al profesor Alfonso García-Gallo, Madrid, 1996, tomo I, pp. 107-163, estudio citado ya en la nota 75 de este artículo.

${ }^{158}$ Alfonso García-Gallo, Introducción al estudio de la Historia del Derecho español (Concepto. Método. Fuentes. Programa), memoria mecanografiada, 105 páginas; Sánchez-Arcilla, «Las oposiciones a cátedra de don Alfonso García-Gallo», p. 115, nota 17.

${ }^{159}$ Sánchez-Arcilla, «Las oposiciones a cátedra de don Alfonso García-Gallo», p. 129.

${ }^{160}$ García-Gallo, Memoria, p. 44; citado por Sánchez-Arcilla, «Las oposiciones a cátedra de don Alfonso García-Gallo», p. 129.
} 
que estaba refiriéndose o aludiendo, en realidad, tan sólo a su situación en la época prehispánica, y no a su existencia o a su pervivencia posterior, como uno de los componentes o elementos integrantes del derecho indiano, lo cual es cosa muy diferente.

Por lo que se refiere al Programa de Historia del Derecho indiano de don Alfonso García-Gallo, puede verse en sus Estudios del año 1987, donde fue publicado también ${ }^{161}$. En una única nota, al pie de la página 1093 de dichos Estudios, el profesor García-Gallo hacía la indicación de que ese programa académico, «con ligeras modificaciones, ha servido de base a las explicaciones de la disciplina en la Sección de Historia de América de la Universidad Complutense de Madrid desde 1944 a $1981 »^{162}$.

Según señalaba el profesor Sánchez Bella en el citado Homenaje que se publicó en 1996, don Alfonso García-Gallo se trasladó a la Universidad Central o Universidad de Madrid - desde la cátedra de Historia del Derecho español de la Universidad de Valencia, que desempeñó durante tres años y a la cual había pasado desde la Universidad de Murcia - al obtener por oposición, en 1944, la cátedra de Historia de las Instituciones políticas y civiles de América, cátedra correspondiente a los estudios de doctorado en las Facultades de Derecho y de Filosofía y Letras ${ }^{163}$. Tuvo a su cargo también, desde 1944 ó 1945, la enseñanza de la Historia del Derecho indiano en la sección de Historia de América de dicha Facultad de Filosofía y Letras. A partir de 1953, a causa de la supresión de la mencionada cátedra de doctorado, pasó a una de las nuevas cátedras de Historia del Derecho español en la Facultad de Derecho, continuando igualmente con la docencia de la Historia del Derecho indiano, hasta su jubilación reglamentaria en el curso académico 1980-1981 ${ }^{164}$.

Volviendo al Programa de Historia del Derecho indiano utilizado por don Alfonso García-Gallo, se trataba de un programa que estaba estructurado o dividido en cuatro partes, en todas las cuales había diversos epígrafes en los que tendría cabida y acomodo la materia del componente indígena o autóctono del ordenamiento jurídico indiano: en la primera parte, «El Derecho y sus fuentes», dentro del apartado «La pluralidad de ordenamientos jurídicos en Indias», el epígrafe «Los Derechos indígenas» ${ }^{165}$; en la segunda parte, «El Estado indiano», dentro del apartado «La Comunidad

\footnotetext{
${ }^{161}$ García-Gallo, «Programa de un curso de Historia del Derecho indiano», en su libro Los orígenes españoles de las Instituciones americanas. Estudios de Derecho indiano, pp. 1.093-1.102.

${ }^{162}$ García-Gallo, «Programa de un curso de Historia del Derecho indiano», p. 1.093, nota.

${ }^{163}$ La cátedra de doctorado de Historia de las Instituciones políticas y civiles de América en la Universidad Central o Universidad de Madrid la tuvo don Rafael Altamira desde 1914 — después de haber sido catedrático de Historia del Derecho en la Universidad de Oviedo a partir de 1897- hasta su correspondiente jubilación en 1936, cuando cumplió setenta años de edad, puesto que había nacido, en Alicante, el 10 de febrero de 1866. En realidad, como indico en otro lugar de este artículo, Altamira se ausentó de España en ese mismo año 1936.

${ }^{164}$ Ismael Sánchez Bella, «García-Gallo y el Derecho Indiano», en Homenaje al profesor Alfonso García-Gallo, Madrid, 1996, tomo I, pp. 165 y 166.

${ }^{165}$ García-Gallo, «Programa de un curso de Historia del Derecho indiano», p. 1.094.
} 
indiana», el epígrafe «La república de los indios» ${ }^{166}$; en la tercera parte, «El gobierno de las Indias», dentro del apartado «El gobierno local», el epígrafe «Los pueblos de indios. Tipos de organización indígena y española», y dentro del apartado «El gobierno de la Hacienda» y en relación con los ingresos de ésta, el epígrafe «El tributo indígena ${ }^{167}$; y en la cuarta parte, «La acción española en Indias», dentro del apartado «La regulación jurídica de la vida económica», el epígrafe «La regulación del trabajo indígena $^{168}{ }^{168}$.

Esta Historia del Derecho indiano impartida por el profesor García-Gallo en la Universidad de Madrid durante muchos años, en fin, no sólo era una asignatura «ordinaria» en la sección de Historia de América de la licenciatura en la Facultad de Filosofía y Letras ${ }^{169}$, sino que tenía también, al mismo tiempo, la finalidad o la utilidad docente de ser un «curso de doctorado» para los licenciados en la Facultad de Derecho ${ }^{170}$.

\footnotetext{
${ }^{166}$ García-Gallo, «Programa de un curso de Historia del Derecho indiano», p. 1.097.

${ }^{167}$ García-Gallo, «Programa de un curso de Historia del Derecho indiano», pp. 1.100 y 1.101.

${ }^{168}$ García-Gallo, «Programa de un curso de Historia del Derecho indiano», p. 1.102.

${ }^{169}$ En un momento posterior se creó en la sección de Historia de América un segundo grupo de docencia, en el cual tuvo a su cargo la enseñanza de la Historia del Derecho indiano el profesor don Juan Manzano, creo recordar que desde no mucho tiempo antes de su jubilación el 31 de octubre de 1981, al cumplir setenta años de edad.

${ }^{170}$ Constaba así, por ejemplo, en el plan de ordenación docente del departamento de Historia del Derecho para el curso académico 1967-1968. José Sánchez-Arcilla Bernal, «Una aportación a la Historia de la Facultad de Derecho de la Universidad Complutense de Madrid. El Departamento de Historia del Derecho (1967-2008)», en Cuadernos de Historia del Derecho, volumen extraordinario dedicado a María Isabel de Grandes Pascual con motivo de su jubilación, Madrid, 2010, pp. 583-645. La referencia al citado plan de ordenación docente para el curso académico 1967-1968 se encuentra en la página 589, nota 14.
} 